\title{
Measuring Age-Friendly Housing: A Framework
}

\author{
Adriana Luciano ${ }^{1,2, *}$, Federica Pascale ${ }^{2}$, Francesco Polverino ${ }^{1}$ and Alison Pooley ${ }^{2}(\mathbb{D}$ \\ 1 Department of Civil, Architectural and Environmental Engineering (DICEA), University of Naples \\ Federico II, 80125 Naples, Italy; polverin@unina.it \\ 2 School of Engineering and the Built Environment, Faculty of Science and Engineering, Anglia Ruskin \\ University, Chelmsford CM1 1SQ, UK; federica.pascale@anglia.ac.uk (F.P.); alison.pooley@anglia.ac.uk (A.P.) \\ * Correspondence: adriana.luciano@unina.it; Tel.: +39-3358-187-215
}

Received: 23 November 2019; Accepted: 20 January 2020; Published: 23 January 2020

check for updates

\begin{abstract}
An ageing population raises the question of providing adequate housing that enables older people to age in place without losing autonomy and independence. Except for the issue of accessibility, no framework exists that specifically outlines a standard to achieve and, as a result, interventions on existing or on new buildings may be inconsistent without leading to a desired rise in living standards. This research addresses this issue by presenting a framework for the assessment of the age-appropriateness of housing through a number of metrics that detect and identify physical and non-physical features of a home environment to enable ageing in place. The study combines data from a qualitative systematic literature review of 93 papers and qualitative data from structured interviews with four experts in the field. As a result, 71 metrics were identified, divided into eight main domains, to describe the framework. This paper provides an improved understanding of the housing features that enable ageing in place. The tool categorizes and rates qualitative and quantitative aspects that contribute to the age-friendliness of housing, resulting in an easy to adopt assessment framework. This is a valuable means for stakeholders engaged in improving the current housing stock or in constructing new buildings for older people.
\end{abstract}

Keywords: ageing in place; housing; ageing population; age-friendly housing; assessment framework

\section{Introduction}

Developments in society dating from the 1960s have led to a demographic change identified as the 'second demographic transition' [1]. One of the main consequences of this unprecedented change is an ageing population [2] resulting from the increase in life expectancy and falling birth rates [3-5]. In the next decades, the number of people aged 60 years or over is expected to more than double [5] and an ever-increasing proportion of them will live in an urban context [6]. According to the World Health Organization (WHO), an ageing population together with urbanization is the major challenge for the 21st century [3,7]. Assuring health and wellbeing in urban settings during later life is becoming a priority issue in both developed and developing countries [3,7]. In order to achieve sustainable development, cities are required to provide services and opportunities tailored to the needs of older people to enable them to participate in society and to be a human resource $[7,8]$. In this sense, older people require a supportive environment to compensate for their physical and social changes [3]. The idea of an 'age-friendly city' has therefore been introduced [3]. It considers the evolving needs of ageing population and provides the structures and the services to promote the residents' wellbeing and productivity, supporting sustainability [3,5]. An age-friendly city is central to the aim of Sustainable Development Goal (SDG) 11 of the 2030 Development Agenda by the United Nations to "make cities and human settlements inclusive, safe, resilient and sustainable" [9]. An age-friendly city, furthermore, promotes active ageing defined as the process of "optimizing opportunities for health, participation 
and security in order to enhance quality of life as people age" [3] (p. 1). Several non-governmental organizations and research institutions, alongside the WHO, have developed strategies to improve lives of older people in their communities. Within such strategies, the built environment is recognized as an area of concern.

The complex blending between physiological, behavioral, social, and environmental changes that occur in the process of ageing is well described by the 'ecological model of aging' by Lawton $[8,10,11]$ which describes the dynamic interplay between the competence of an individual and the environmental press over their life course. According to the model, adaptive behavior comes from the balance between competence and environmental press: This means that challenges posed by the environment that do not match personal capacities, negatively impact on behavior and wellbeing. Older people are, therefore, more exposed to environmental challenges because of their increased vulnerability [12]. Proceeding from the fact that the major context for ageing is provided by housing, and that independence in activities of daily living is a health indicator, the fundamental role played by housing in the life of older people is clear $[13,14]$. Research reports that over time the significance of home increases $[15,16]$ and the relationship between people and their homes becomes ever more important [17]. This is reflected in the fact that older people generally wish to remain in their own home for as long as possible [16,18-20]. Ageing in place [21] has emerged as a strategy to improve the quality of life of older people enabling them to stay longer in their own home before institutionalization, whilst reducing public and private health spending [22]. To enable ageing in place, housing must be adequate to accommodate the needs of older people. This is also mentioned in SDG 11 which sets the objective of ensuring "access for all to adequate, safe and affordable housing" [9] (p. 21). Several organizations have listed the criteria that make housing adequate for the needs of older people.

In 2007 the WHO wrote the Global Age-friendly Cities: A Guide [3], containing a checklist of the core features that help cities become more age-friendly. To develop this guideline, focus groups were conducted among older people, caregivers, and service providers in 33 cities across all continents, exploring a total of eight topics. The topics reflected the determinants of active ageing and, for each of them, a checklist was outlined. Housing is one of the topics related to the built environment together with outdoor spaces and buildings and transportation. The features that affect its age-friendliness are grouped into nine domains: Affordability, essential services, design, modifications, maintenance, ageing in place, community integration, housing options, living environment. For each domain, the most common issues faced by, and the most common expectations displayed by the older people were reported. As the research gives a summary of the views expressed by the participants worldwide, it can be considered as a relevant overview of the topic. However, the contents of this guide are of a theoretical nature and they provide only an overview of the issues, failing to provide metrics for assessment. In case stakeholders want to use it as a guideline for their action plans, they must confirm the validity of the checklist and adapt its contents to the local context in order to obtain an assessment that is most appropriate for the local community $[7,23]$. In 2015 the American Association of Retired Persons (AARP) launched the Livability Index as a tool to assess and compare the community livability of cities and towns across the United States [24]. The average value scored by all communities across the U.S. represents the reference point for the assessment. Livability is evaluated according to seven major categories including housing and, for each category, a number of metrics and policies are combined to obtain the score. These metrics give a practical way to assess housing features but they are evaluated by comparison with the national standards, therefore they are not suitable to assess the community livability outside the United States. The AARP Home Fit Guide [25], instead, gives a more detailed description of the features that make a dwelling suitable for an older person. It is a tool designed to help people assess their home environment and modify it according to their own needs. The Housing our Ageing Population Panel for Innovation (HAPPI) developed ten principles to guide the design of housing for older people in order to improve their quality of life [26]. Such guidelines, which in many cases are based on good design principles, can be considered as a reference in approaching a new project but not tools to assess the age-friendliness of houses. 
Alongside the concept of homes tailored on the needs of older people, that has resulted in guidelines and design standards, a concept that is gaining increasing interest is that of lifetime homes. It refers to the ability of a home environment to adapt to the changing needs of individuals during their lifespan. This encapsulates a broader interpretation of the suitability of housing, extending to the whole life course of a person. Organizations like Foundation for Lifetime Homes and Neighborhoods and the AARP have proposed design principles to prepare a house to easily and cost-effectively accommodate future adaptations $[27,28]$.

The aforementioned guidelines can be considered as design standards, but they cannot be used to assess current housing and to prioritize interventions. Furthermore, while a large and growing body of literature has investigated the extent to which environmental features affect perceived and objective health of older people, less attention has been directed to the assessment of the quality of housing to enable an understanding of the degree of compliance of a home environment with the needs of its inhabitants. The need for metrics and assessment tools is mentioned to establish a common understanding among stakeholders, set goals, and monitor the effects of interventions [7]. In order to address this gap, the present research aims to identify features that impact on the age-friendliness of housing and integrate them in a theoretical framework that can serve as a foundation for developing an evaluation tool. To achieve the aim, the research approach integrates the results of two different methods. Firstly, a qualitative systematic review was conducted. Data on the features of dwellings that have been proven to impact the life of older people were collected. Based on these data, the metrics of the framework were developed and for each metric a score system was defined. The model was then validated through experts' opinion.

This study provides three major contributions. Firstly, it updates, contextualizes and operationalizes the theoretical framework proposed by WHO [3] in relation to the common housing types of Western European countries. Secondly, as age-friendly cities are a policy goal shared by most of these countries and housing one of the eight determinants of an age-friendly city, this research offers an in-depth analysis of housing features relevant for older people. Lastly, it provides a tool to assess the age-friendliness of housing. This can be a useful decision support system for stakeholders (policymakers, technicians, homeowners, occupants/residents) to address interventions in existing housing or when designing new housing.

\section{Materials and Methods}

To identify the features that impact on age-friendliness of housing and to translate them in terms of metrics, the following steps were taken. Firstly, through a qualitative systematic review the features reported by researchers as impacting on the wellbeing of older adults were recorded and organized into eight domains, which form the structure of the framework. For each domain a list of metrics was outlined and then associated to a score system corresponding to the different levels of housing quality. The metrics and the score system were examined by a panel of experts through a questionnaire in which they expressed their degree of agreement on a Likert scale. Furthermore, through textual commentary they proposed changes in the metrics and/or in the rating system.

\subsection{Qualitative Systematic Review}

The purpose of the literature review was to establish the features of houses that enable older people to live well in their homes and express them in terms of architectural performance requirements. These constitute the metrics of the age-friendly housing framework.

The following electronic databases were searched: PubMed, Emerald Insight, Scopus, and Web of Science. They were selected because of their different main subject areas, which could provide a thorough overview of the topic. In order to include the maximum possible number of relevant studies, the search strings included general keywords referring to both the home environment and ageing. A common query was formulated and, according to the syntax of each database, a number of specific queries were used to narrow down to the field of interest. The searches generated 1844 matches. The titles and the abstracts of 
the papers were examined to determine if they were suitable for the research purpose; exclusion criteria were listed and duplicates were detected. After the first screening phase, 99 articles were selected to be fully read. This first step allowed to identify the leading dimensions of age-friendliness of housing and to define the domains of the framework. According to the topics covered by the domains, 29 papers were considered eligible as they presented contents useful for identifying the metrics needed to operationalize each domain. To further investigate the domains, new search questions were formulated. The questions were firstly addressed through a snowball sampling method that consisted in selecting from the reference lists of the 29 eligible papers other relevant papers that dealt with the domains of the framework. Then, the search was extended to recommendations, guidelines, conference proceedings, reports, and policy documents. As a result, 64 papers were added leading to a total number of 93 papers being included in the review (Figure 1).

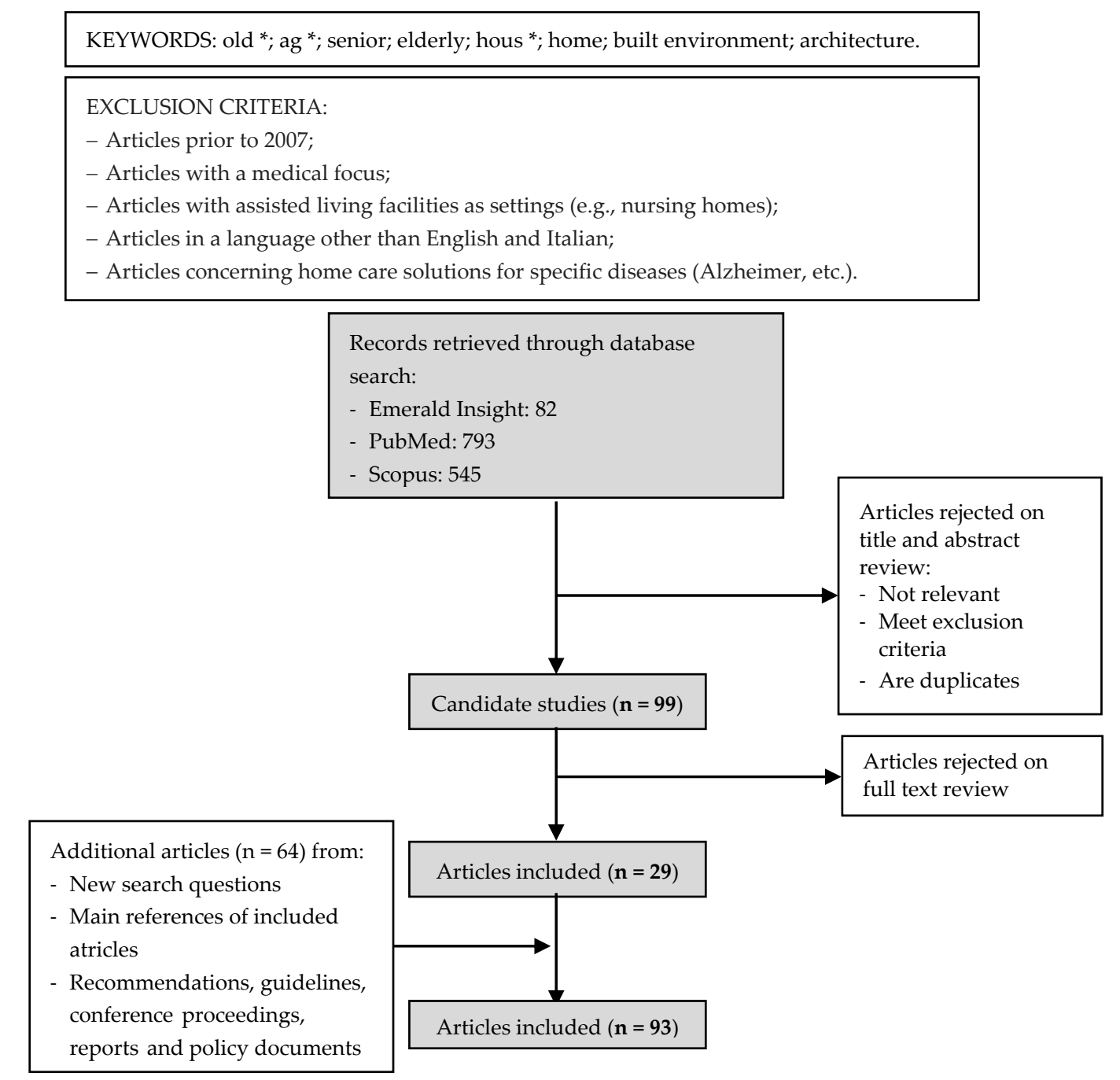

N.B. the asterisk used in the keywords matches any character zero or more times. It has been used to include in the same search string more words with the same root (e.g., ag * includes aging, ageing, age).

Figure 1. Keywords and flow chart of literature review.

\subsection{The Experts' Opinion Technique}

An indicator can be defined as a means to supply simplified information about a complex system or an unmeasurable criterion [29]. This is the case of age-friendliness of housing for which no tangible parameters could be directly detected. As the framework presented in this paper is the theoretical 
basis to the indicator of age-friendliness of housing, validating its contents was considered of utmost importance. A conceptual validation was therefore undertaken to be sure that the framework describes the complexity of the phenomenon and that it is fit for purpose [30,31]. According to Inglis [32], referring to the appropriate research literature is a well-founded strategy to validate a framework. However, appealing also to a panel of experts and asking them to express their opinion about the comprehensiveness of the framework, leads to a more rigorous validation [32]. For this purpose, a panel of experts was involved in the research.

The panel was selected to be as heterogeneous as possible: Its members come from different fields of knowledge reflecting the range of stakeholders who have an interest in the results of the study. The members of the panel are Italian, and their backgrounds are medicine, architecture, academia, and social housing management. They were firstly contacted to be informed about the aim of the study and to invite them to participate. Of the eight experts that were contacted, four accepted to take part in the research and were included in the panel.

The experts were asked to answer a questionnaire between September and October 2019. They were mutually anonymous as is common practice to avoid undue influence by certain members of the panel [33-35]. The questionnaire was sent via email: It contained a brief summary of the research, the metrics of the indicator, and the related score system. For each metric, the major references, the description of the parameter, and the way to measure it were reported. Experts were asked to answer the following questions:

- Do you agree with the score scale? Expand on your answer.

- Do you think that the contents of this metric are comprehensive? If not, write any other content that you think is useful.

Panelists expressed their agreement on a five-point Likert scale $(1=$ completely disagree, $5=$ completely agree) that is considered the most adequate scale to provide information about the opinion of a person [36]. Motivations and suggestions were reported in open written responses. Given the small number of panelists, the mean of the agreement expressed for each metric was calculated and a qualitative assessment of their opinion was undertaken during a research team workshop. Values under 3 were considered in disagreement with the proposed metric; values between 3 and 4 were considered in slight agreement, and values over 4 were considered in full agreement.

\section{Results from Literature Review}

The literature review led to the outline structure of the framework of age-friendly housing in which the most recurring determinants of housing quality were reported. The structure of the framework is based on the checklist proposed by WHO [3] (Table 1). It brings together the major concerns to consider when assessing the suitability of dwellings to the needs of older people. The framework has therefore been structured in eight domains as follows (Figure 2): Affordability, community connection, access to services, safety and security, essential services, design, modification, maintenance. Compared to the checklist, the framework does not mention 'housing option' as it was not considered useful to assess the age-friendliness of housing, but rather the availability of living options. Furthermore, to be more consistent with the topics addressed in the checklist, the domains 'living environment' and 'ageing in place' were renamed respectively 'safety and security' and 'access to services.' The other six domains overlap those reported in the guide by WHO. For each domain, an extensive understanding has been provided through the analysis of the literature review (Table 2). The following paragraphs reflect the structure of the framework presented in Figure 2. 
Table 1. Age-friendly housing checklist. Source: World Health Organization (WHO). Global age-friendly cities: A guide; WHO: Geneva, 2007 [3].

\begin{tabular}{|c|c|}
\hline Affordability & Affordable housing is available for all older people. \\
\hline Essential Services & Essential services are provided that are affordable to all. \\
\hline \multirow{4}{*}{ Design } & Housing is made of appropriate materials and well-structured. \\
\hline & There is sufficient space to enable older people to move around freely. \\
\hline & Housing is appropriately equipped to meet environmental conditions. \\
\hline & $\begin{array}{l}\text { Housing is adapted for older people, with even surfaces, passages wide enough } \\
\text { for wheelchairs, and appropriately designed bathrooms, toilets and kitchens. }\end{array}$ \\
\hline \multirow{5}{*}{ Modifications } & Housing is modified for older people as needed. \\
\hline & Housing modifications are affordable. \\
\hline & Equipment for housing modifications is readily available. \\
\hline & Financial assistance is provided for home modifications. \\
\hline & $\begin{array}{l}\text { There is a good understanding of how housing can be modified to meet the needs } \\
\text { of older people. }\end{array}$ \\
\hline \multirow{3}{*}{ Maintenance } & Maintenance services are affordable for older people. \\
\hline & $\begin{array}{l}\text { There are appropriately qualified and reliable service providers to undertake } \\
\text { maintenance work. }\end{array}$ \\
\hline & Public housing, rented accommodation and common areas are well-maintained. \\
\hline \multirow{3}{*}{ Ageing in Place } & Housing is located close to services and facilities. \\
\hline & $\begin{array}{l}\text { Affordable services are provided to enable older people to remain at home, to } \\
\text { "age in place". }\end{array}$ \\
\hline & Older people are well-informed of the services available to help them age in place. \\
\hline Community Integration & $\begin{array}{l}\text { Housing design facilitates continued integration of older people into the } \\
\text { community. }\end{array}$ \\
\hline \multirow{5}{*}{ Housing Options } & $\begin{array}{l}\text { A range of appropriate and affordable housing options is available for older } \\
\text { people, including frail and disabled older people, in the local area. }\end{array}$ \\
\hline & Older people are well-informed of the available housing options. \\
\hline & $\begin{array}{l}\text { Sufficient and affordable housing dedicated to older people is provided in the } \\
\text { local area. }\end{array}$ \\
\hline & $\begin{array}{l}\text { There is a range of appropriate services and appropriate amenities and activities } \\
\text { in older people's housing facilities. }\end{array}$ \\
\hline & Older people's housing is integrated in the surrounding community. \\
\hline \multirow{5}{*}{ Living Environment } & Housing is not overcrowded. \\
\hline & Older people are comfortable in their housing environment. \\
\hline & Housing is not located in areas prone to natural disasters. \\
\hline & Older people feel safe in the environment they live in. \\
\hline & Financial assistance is provided for housing security measures. \\
\hline
\end{tabular}




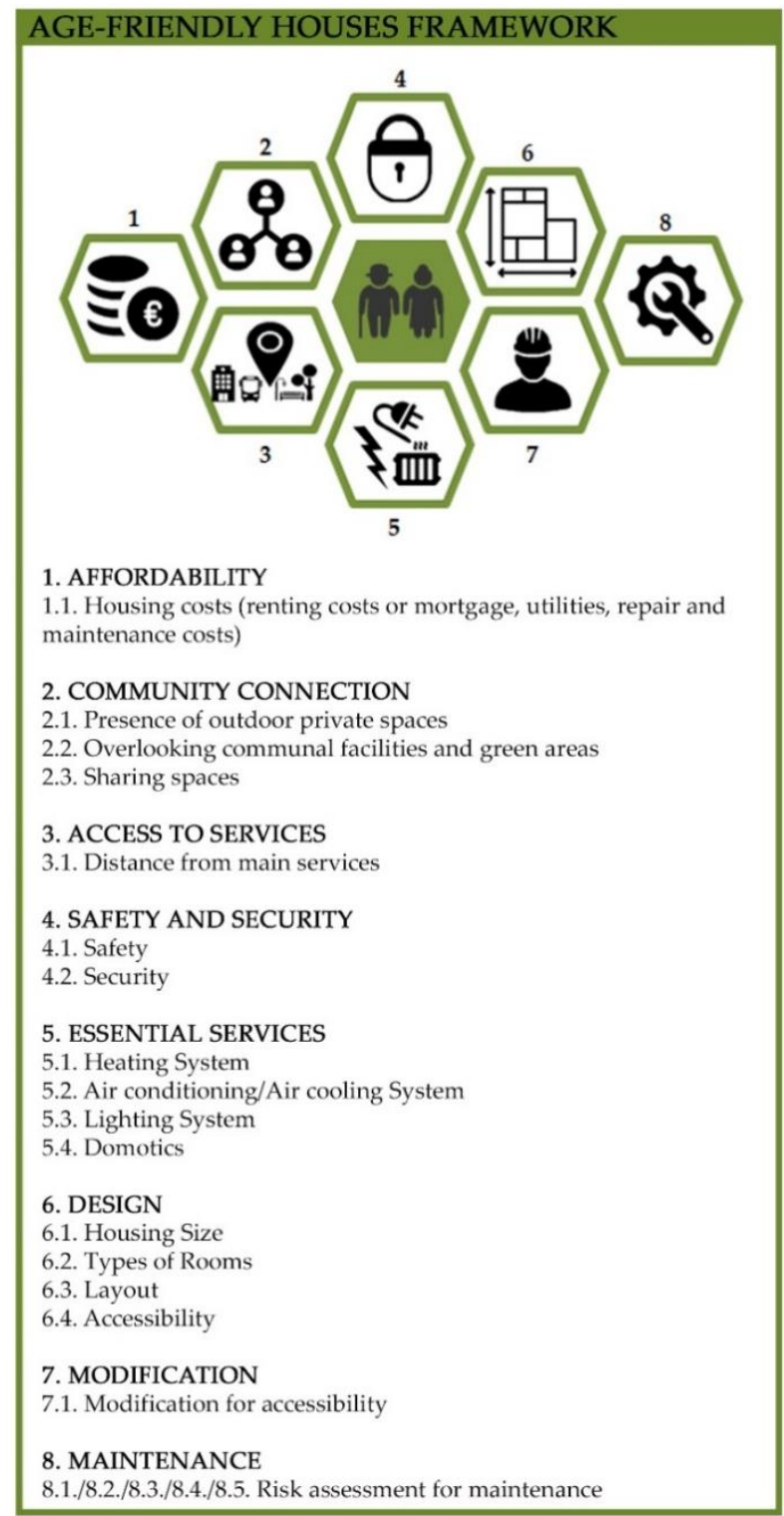

Figure 2. Age-friendly housing framework. 
Table 2. Results of literature review divided by domain.

\begin{tabular}{|c|c|c|}
\hline Domain & Metric & Reference \\
\hline \multirow[t]{4}{*}{ 1. Affordability } & Housing costs including: & {$[3,7,24,37-39]$} \\
\hline & - $\quad$ Renting cost or mortgage payment & \\
\hline & - $\quad$ Utilities & \\
\hline & - $\quad$ Repair and maintenance costs & \\
\hline 2.1. Community connection & Presence of outdoor private spaces & {$[3,26,40-46]$} \\
\hline 2.2. Community connection & Overlooking communal facilities and green areas & {$[3,23,26,41,44,47-50]$} \\
\hline 2.3. Community connection & Presence of sharing spaces & {$[46,48,49,51,52]$} \\
\hline \multirow[t]{8}{*}{ 3. Access to Services } & Proximity of the house to the following amenities: & {$[3,7,20,24,43,46,50,52-64]$} \\
\hline & - $\quad$ Health facilities & \\
\hline & - $\quad$ Community centers & \\
\hline & - $\quad$ Shops & \\
\hline & - $\quad$ A stop of a public transport & \\
\hline & - $\quad$ Parks & \\
\hline & - $\quad$ General services (bank, public services, etc.) & \\
\hline & - $\quad$ Places of worship & \\
\hline 4.1. Safety and security & Safety & {$[52,59,65-78]$} \\
\hline 4.2. Safety and security & Security & {$[3,7,46,53,79-82]$} \\
\hline 5.1. Essential services & Heating system & {$[3,47,48,79,81,83-87]$} \\
\hline 5.2. Essential services & Air conditioning/air cooling system & {$[26,83,85,87]$} \\
\hline 5.3. Essential services & Lighting system & {$[76,77,85,88-90]$} \\
\hline
\end{tabular}


Table 2. Cont

\begin{tabular}{|c|c|c|}
\hline Domain & Metric & Reference \\
\hline 5.4. Essential services & \begin{tabular}{ll}
\multicolumn{2}{l}{ Domotics with reference to: } \\
- & Lighting system \\
- & Doors and windows opening and closing system \\
- & Heating and air conditioning systems \\
- & Water system \\
- & Alarms systems \\
- & Smart meters
\end{tabular} & {$[26,47,52,76,83-85,91-94]$} \\
\hline 6.1. Design & Housing size & {$[46,48,59,89,95-97]$} \\
\hline 6.2. Design & Rooms type & {$[3,26,41,46,48,79,85,98,99]$} \\
\hline 6.3. Design & Layout & {$[48,59,69,85,94]$} \\
\hline 6.4. Design & $\begin{array}{ll}\text { Accessibility with reference to: } \\
- & \text { Pathway to approach house } \\
- & \text { Entrance } \\
- & \text { External stairs and lift } \\
- & \text { Internal doors } \\
- & \text { Hallways } \\
- & \text { Windows } \\
- & \text { Kitchen and living room } \\
- & \text { Bathroom } \\
- & \text { Bedroom } \\
- & \text { Fixed furnishing } \\
- & \text { Internal stairs } \\
- & \text { Electrical outlets, counters, and systems terminal in general } \\
- & \text { Balconies and terraces }\end{array}$ & {$[19,27,69,89,100-107]$} \\
\hline
\end{tabular}


Table 2. Cont

\begin{tabular}{|c|c|c|}
\hline Domain & Metric & Reference \\
\hline 7. Modification & \begin{tabular}{ll}
\multicolumn{2}{l}{ Interventions needed to make accessible: } \\
- & Pathway to approach house \\
- & Entrance \\
- & External stairs and lift \\
- & Internal doors \\
- & Hallways \\
- & Windows \\
- & Kitchen and living room \\
- & Bathroom \\
- & Bedroom \\
- & Fixed furnishing \\
- & Internal stairs \\
- & Electrical outlets, counters, and systems terminal in general \\
- & Balconies and terraces \\
- & Multi-level house
\end{tabular} & {$[3,38,55,57,67,69,73,85,97,101,104,108-114]$} \\
\hline 8.1., 8.2., 8.3., 8.4., 8.5. Maintenance & $\begin{array}{l}\text { Risk assessment for maintenance with reference to: } \\
\text { - } \quad \text { Cleaning and control interventions to undertake at least one time } \\
\text { over a seven-day period. } \\
\text { - } \quad \text { Cleaning and control interventions to undertake at least one time } \\
\text { over a 30-day period. } \\
\text { - } \quad \begin{array}{l}\text { Inspections, checks, revisions, or replacements to undertake at least } \\
\text { every six months }\end{array} \\
\text { - } \quad \begin{array}{l}\text { Inspections, checks, revisions, or replacements to undertake at least } \\
\text { every year. }\end{array} \\
\text { - Preventative maintenance or replacement of parts at risk to } \\
\text { undertake at least every five years. }\end{array}$ & {$[3,46,55,115-122]$} \\
\hline
\end{tabular}




\subsection{Housing Costs}

According to $\mathrm{WHO}$, affordability is "a major factor influencing where older people live and their quality of life" [3] (p.30). The authors of [37] report that housing costs are the major economic challenge for most low-income older people. Housing costs can be a barrier to ageing in place and reduce the ability to afford other vital expenses [38]. There is a common agreement that $30 \%$ of the monthly income is the maximum an older adult can allocate to housing costs (renting cost or mortgage payment, utilities, repair and maintenance costs) without being considered at risk [7,39]. In the USA the Livability Index proposes a threshold that corresponds to the average expenditure for housing costs, measured at a neighborhood scale of $17.9 \%$ [24].

\subsection{Community Connection}

Feeling part of the local community contributes to the age-friendliness of a city [3]. According to WHO [3] the design of housing can facilitate community interaction on multiple levels.

\subsubsection{Presence of Outdoor Private Spaces}

Research reports that housing can impact on a feeling of community connection through outdoor spaces that connect the dweller to the neighborhood: Balconies, patios, gardens, porches, terraces are all elements that can promote socialization and interaction of older people in the neighborhood [3,26,40-44]. Concerns are expressed about high-rise buildings and modern flats without outdoor spaces because they impede personal contact with neighbors [3]. To be suitable for the needs of older people, outdoor spaces should meet a list of minimum requirements, which are: Accessibility, adequate size to accommodate furnishings (like chairs and tables), protection against atmospheric conditions, and a certain degree of privacy $[26,41,45,46]$.

\subsubsection{Overlooking Communal Facilities and Green Area}

Older people can benefit from a view of external spaces $[3,26,47]$. Overlooking communal facilities and establishing a physical and visual relationship with the surroundings makes older people more involved in the community and helps to reduce their sense of isolation [3,44,48,49].

There is a consensus among researchers that the quality of the view plays an important role in reducing the feeling of loneliness and on the general wellbeing of individuals [23,26,50]. For example, for older people that spend most of the day at home, overlooking green areas can be the main way they interact with natural elements [41], which in turn has a positive impact on wellbeing [41,48].

\subsubsection{Sharing Spaces}

Providing meeting places is important [49]. "Communal areas are not just a way of avoiding loneliness; they are a positive opportunity to socialize, take part in activities or be entertained" [48] (p.60). Sharing spaces, providing opportunities to meet, and organizing communal activities reduce the likelihood of social isolation, loneliness, and depression [46,51]. Participation of the older people in the design process of such spaces is also recognized as a key point in creating a strong bond within the community [52].

\subsection{Distance from Main Services}

The location of housing can have a great impact on its desirability and several benefits are recognized in living close to a high number of amenities [53]. It is considered of utmost importance for the independence of older people to be able to access basic services located within short distances from home, such as shops, health care facilities, public transportation, community centers, leisure facilities, parks, places of worship, and public services $[3,46,54,55]$. The extent to which the proximity of such places is important in older people's daily lives varies according with the type of amenity [56]. Place connectivity contributes to establish a social link within the community [43,56-58] and encourages 
physical activity with positive implications on health and wellbeing [50,54,57,59-61]. The distance commonly accepted to be easily walkable by older people is 500 meters which corresponds to a 10-minute walk $[7,53,62,63]$. In the tool proposed by AARP, this distance is a half-mile [24], whereas in the guidelines proposed by the project Welfare housing policies for senior citizens (Wel_hops) [46] it is suggested that essential services should be less than 400 meters from the home. A cause of concern is the quality of the pathway whose features can hinder walkability of neighborhoods and prevent older people from going outside $[7,20,52,57,60,62,63]$. Literature identifies the following features as fundamental for neighborhood walkability: Safety (including safety from traffic and vehicles) $[3,6,20,46,57,60,62,63]$, street lighting [21,46], availability of pathways and sidewalks in good repair $[3,7,20,46,52,54,62]$, availability of resting places along pedestrian routes [3,52,54], absence of obstacles, and appropriate design [52,57]. However, the extent to which architectural features can promote mobility in older age depends on the interplay between the person and the environment: Barriers must be considered in relation to the personal capacities and the psychological resources of individuals [64].

\subsection{Safety and Security}

\subsubsection{Safety}

Older people are exposed to a number of hazards in the home environment and, among them, falls are the most recurring [65-67]. Besides personal determinants of the inhabitants like age or health status, the features of the home environment greatly impact on the occurrence of falls [65-73]. The most common risk factors for falls are: Slippery surfaces, low chairs, absence of grab bars or handrails, loose rugs, no arm rest on chairs, missing second banister on stairs, poor lighting, obstructed pathways, and storage areas out of reach [69,72-77]. Modifying the home environment is considered an effective way to reduce the likelihood of falling $[67,72,78]$, especially when modifications are combined with other measures aimed at increasing awareness of risks by older people [65,70]. According to the findings, simple interventions such as grab bars and handrails, shower seats, raised toilet seats, anti-slip surfaces, visual cues that outline a pathway at night from bed to bathroom, and fall-detection systems that call those who are able to help, are highly recommended $[52,59,65,77]$.

\subsubsection{Security}

A cause of concern for older people is feeling safe in their living environment [3]. Security from crime is the major aspect of neighborhood satisfaction $[79,80]$ and impacts on health and mental wellbeing of older people [7]. The overall crime rate of the area where the housing is located is an important determinant of a sense of security for older people [81]. This aspect, along with neighborhood deterioration, affects their trust and social ties [82]. Apart from the neighborhood crime rate, the physical security features of housing need to be considered as a means to prevent burglars and intruders [3]. Poor external lighting, inadequate locks and chains to windows and doors, lack of burglar alarm systems, and lack of barriers along the boundaries are the major predictors of an unsecure dwelling $[3,53,81]$. Surveillance cameras, absence of hiding places around the house, window locks, chains on entrance doors, gates on the boundaries, and use of a concierge or security system are the most common dissuasive means against intrusion $[3,46,53,81]$. Another aspect to take into account when assessing perceived security is sharing of the home environment: Older people that live alone are more likely to feel insecure in their home [3].

\subsection{Essential Services}

The metrics for the framework presented here assume that the minimum requirements for essential services (i.e., presence of water, electricity) are generally guaranteed in all dwellings.

\subsubsection{Heating System}

According to the authors of [83] (p.126), "environmental conditions that are within the comfort zone can positively contribute to the health and well-being of people to age-in-place." Frailty due to 
health conditions makes older people more vulnerable to environmental conditions [48], even more so if they are affected by dementia [83-85]. Studies report that for people with dementia, the internal environment is an important parameter to provide comfort and help manage problem behavior $[84,85]$.

Living in houses where indoor temperatures are low is a great concern for older adults; below $16^{\circ} \mathrm{C}$ they are exposed to serious health risks, including risk of respiratory and cardiovascular conditions [81]. According to the WHO there is no demonstrable risk to human health when the temperature is between $18^{\circ} \mathrm{C}$ and $24^{\circ} \mathrm{C}$ but a higher minimum value may be necessary for vulnerable groups, including older people [86]. The authors of [83] stated that older people have different comfort needs compared to the younger population groups. These differences have been proved in a number of studies in terms of deviation from the comfort zone of the younger population [83]. With reference to a $20-24{ }^{\circ} \mathrm{C}$ comfort zone, for example, the authors reported that this range is not warm enough for older adults as they generally prefer a warmer environment $\left(+2{ }^{\circ} \mathrm{C}\right)$ [83]. Assuring that older people can control the indoor temperature is therefore important to support individual thermal preferences and improve satisfaction $[47,79,83]$.

Heating costs also represent a concern for adults, especially for those with a reduced income $[83,84]$. Research evidences that in many cases older people on a low income are willing to use little or no heating with a high risk to their health [84]. Strategies to reduce energy costs, increase comfort, and save money should therefore be pursued $[48,83,84,87]$.

\subsubsection{Air Conditioning System}

As with low temperatures, older people are particularly vulnerable to heat causing serious health problems that can lead to death [87]. Homes need to be well-insulated, well ventilated, and able to avoid overheating through passive solar design such as thermal mass and solar blinds [26,85]. In more extreme climates where high temperatures are experienced over longer periods of time, comfort can be provided by the installation of air-conditioning units [26,85]. In this case, energy-saving systems are also strictly recommended [83].

\subsubsection{Lighting System}

Lighting is an important feature of the home environment because of its multiple functions for the wellbeing of older people: It is essential for vision, regulating biochemical processes, and reducing fall risks and sleep disorders [77,85]. Furthermore, inadequate lighting is one of the reported barriers that older people experience in order to participate safely in social and physical activities, which impacts their independence and social life $[77,88,89]$. Due to deteriorating vision, older people need a brighter environment to perform activities compared to younger adults [89]. Within the home environment, glare should be minimized, for example shielding natural light, and all the ambient and task areas should be adequately illuminated $[76,90]$. Location and type of switches are also important: They should be located near the bed and near the door to be easily operated and should be equipped with dimmers to control light intensity $[76,90]$.

\subsubsection{Domotics}

Introducing technology into the design of homes is regarded as a means to support ageing in place, as well as to facilitate the implementation of health-care services $[26,52,83,91]$. The great number of opportunities that technology provides in terms of management and control of the home environment could be summarized into four categories: 1) Vital signs monitoring; 2) lifestyle monitoring; 3) mobility and falls monitoring; and 4) domestic environment monitoring [92]. The last category includes smart home technologies that use electronic information to control and manage internal environmental conditions, adapting to residents over time $[83,84,92]$. Electronic systems in smart homes can even perform certain tasks without requiring input from residents: This is particularly important to enhance independence in situations with little or limited physical activity [84,91,93]. Fall-detection systems, alarms (i.e., leaking gas alarm), and emergency call systems meet the need of older people for safety and 
security $[47,52,76]$. Authors agree that technology, to be effective, must be familiar and non-invasive in a way that permits older people to easily understand and operate $[47,76,85,91-93]$. This is even more important for people living with dementia as home automation can lead to confusion and anxiety if older people do not have control of it [94].

\subsection{Design}

Housing design impacts the ability of older people to live comfortably at home in several ways [3]. In this study, four areas of investigation have been determined to summarize such features. They are: Housing size, rooms type, layout, and accessibility.

\subsubsection{Housing Size}

In terms of dimension of spaces, housing size must be adequate to enable older people to safely perform activities of daily living [89]. The authors of [95] found that housing size, expressed in square meters, was differently associated to life satisfaction in relation to the age of inhabitants. The young-old (65-80 years) experience high life satisfaction when living in larger homes whilst older-old (80 years and older) are more satisfied if their homes are smaller. According to the authors, this comes from the different ways to interact with the environment with ageing, reflecting the differences in terms of a "proactive use of environmental richness in third age versus a docile adaptation to environmental press in fourth age" [95] (p.247). No specific housing size standards have been established until now. The authors of [48] report that minimum gross floor areas in an age-friendly apartment should exceed at least $10 \%$ the English national standard for common housing. Houses with reduced space for maneuvering, doing activities, or just moving are considered unsafe for older people [59]. Conversely, spacious properties that overwhelm older people can cause a number of problems related to mobility and to property management in general $[46,59]$. The impact housing size has on physical activities must also be considered: Studies have found that large homes require more physical efforts per day with positive effects on health $[96,97]$.

\subsubsection{Types of Rooms}

Overcrowding, defined as "the condition where the number of occupants exceeds the capacity of the dwelling space available, whether measured as rooms, bedrooms or floor area, resulting in adverse physical and mental health outcomes" [86] (p.22) is a concern for older people [3]. According to the measure of crowding proposed by Eurostat, a room should be provided for every older adult apart from couples that could share [98]. This form of measurement has been introduced in the metric. Findings report that outdoor spaces offering an accessible extension to the home, like balconies, gardens, patios, and terraces, are positively associated with the wellbeing of older people $[26,41,48,85,99]$. The positive effects of exposure to daylight, the contact with nature and the physical activity of gardening are some of the reasons why older people experience physical and mental benefits. The additional need of a room for a caregiver is also mentioned by authors [46,85]. Furthermore, Lawton [79] states that having two bathrooms is the strongest predictor of housing quality satisfaction among older people.

\subsubsection{Layout}

Given that older people are not a homogenous group, it is useful that housing provides flexibility to adapt to their specific needs [48]. Semi-open plan layouts that provide a possibility to arrange living, cooking, and eating spaces, and to easily change this arrangement over time, are suggested [48]. As older people tend to restrict their activities to a smaller range in order to comfortably reach them, attention must be paid to the distances that separate the most commonly used rooms [59]. As a general rule, reducing the number of doors, hallways, and rooms is recommended [69]. The concern of providing the right layout in the house is increasingly raised if inhabitants are affected by dementia. In this case, the authors of $[85,94]$ underline the necessity of open floor plans in order to have an overview of all spaces from all positions in the home. According to the authors, making the toilet visible from the living room is 
fundamental to help older people to easily locate it and connecting the bathroom with the bedroom is also important to reduce the risk of falling.

\subsubsection{Accessibility}

Accessibility is a crucial feature to consider when designing housing for older people [69] given the requirement for a barrier-free environment resulting from increasing functional decline [100,101]. Accessibility is a more critical aspect for older people living alone in case they have no household members to help them perform the activities of daily living [101]. There is a common understanding among researchers of the main problems attributable to barriers within the home environment: Loss of independence, social isolation, elevated risk of injury, reduction of life satisfaction, and high health carer needs $[19,89,100,102-104]$. In addition, evidence shows a contraction of spending on institutionalization associated with living in a more accessible home environment [19,101,102]. The absence of barriers, resulting in a more secure living environment, reduces fall risk and the medical consequences of injuries, facilitating ageing in place $[19,89,101,102]$. The authors of [89] also highlight the importance of accessibility of household appliances to meet the needs of older people. Adaptability of dwellings to make them accessible when disability appears is also considered an age-friendly feature [101].

In Italy the Ministerial Decree 236/1989 has defined accessibility through several environmental features that allow a person with reduced mobility to easily make use of the space [105]. As the framework here presented is tested in Italy, the indications contained in the Italian Ministerial Decree have been regarded as minimal technical requirements. Such requirements have been enhanced with reference to those reported in the Swedish Housing Enabler Instrument [106,107] and in the English Lifetime Homes Revised Criteria [27].

\subsection{Modification for Accessibility}

Being able to modify home environments in terms of size, space organization and functions to adapt to the changing needs of people as they age, affects the ability of individuals to age in place $[3,38,55,57,108]$. Home modifications can reduce the gap between environment and physical capacity [109]; especially for people living with dementia that are no longer able to adapt to their environment [85]. Even if benefits can be achieved by adopting either standard or personalized modifications [97], the types of interventions and their impact on wellbeing are highly individual [104]. There is a consensus in the literature on the several benefits arising from home modifications: Improving accessibility, preventing falls, promoting safety, reducing difficulty in performing everyday life tasks, and reducing the need for health care [38,67,69,97,104,109-111]. However, to be fully effective, interventions on dwellings must be combined with other strategies such as fall-prevention programs $[85,110]$.

The authors of [112] show that, after home improvements, a high percentage of older people can expect to delay institutionalization by 10 years with a great reduction in long term care spending. Costs and difficulty in engaging tradespeople are frequently reported as the main obstacles of home modifications $[3,67,69,73,108,113]$. These problems are widely acknowledged for complex interventions such as adding a bedroom on the first floor, widening doorways or installing a lift [108]. However, also simple and cost-effective interventions are associated with improvements in an older person's daily life. Grab bars, handrails, shower seats, and raised toilet seats are the most frequently mentioned $[38,67,109,114]$. To facilitate these interventions, it is of utmost importance that housing is easily adaptable and suitable for such changes [108,114].

An association has been found between the waiting time for home modifications and the difficulty in performing activities of daily living [104]. Furthermore, the authors of [101] and Demirkan [114] noted the lack of a preventive culture of home modification: Interventions are generally undertaken after a disability has already appeared and not to prevent it. 


\subsection{Risk Assessment for Maintenance}

Regular maintenance is essential to ensure a safe and healthy environment in which a person can age in place [55,115-118]. Poorly maintained homes increase worry and stress, the risk of illness, disease, and injury, as well as increased spending on utility bills and repairs due to the lack of maintenance $[115,117-119]$. Frequently older people are worried about being able to maintain the upkeep of their home environment $[3,55]$. This concern is reported as a key reason to enter residential care where repairs and maintenance are managed by others $[117,119]$. The costs involved in maintaining and making repairs are the first obstacle to predictable maintenance especially for older people on a low-income $[3,117,119,120]$. This also determines the deferral of repairs and maintenance [119] with the aforementioned consequences. Another cause of concern for older people is to be able to get tradespeople [3,119]. Therefore, relying on assistance with home repairs and maintenance provided by associations, persons of trust, or family is considered an age-friendly measure $[3,119,121]$. Studies $[46,117]$ report that being involved in home maintenance tasks benefits the autonomy and wellbeing of older people and their participation in such activities should be supported.

To define the metric of the framework, the mapping of maintenance risk proposed by Molinari [122] and by the American Association of Retired Persons [115] have been used for guidance, meaning that the framework assesses preventative maintenance as the best strategy.

\section{Results from the Experts' Opinion}

Of the 17 metrics assessed by experts, $10(58.8 \%)$ received a full agreement, six (35.3\%) received a slight agreement, and only one (5.9\%) received a disagreement. Comments and suggestions written by experts were then considered. If they were aligned with the findings, the metric remained unchanged. If they disagreed with the metric, two possible options were evaluated. The first option occurred in the case of a thoroughly argued dissent that raised questions not addressed in the literature review. If so, the metric was improved according to the experts' opinion. The second option took place when dissent was motivated with arguments in clear contrast to the literature review. If so, they were ignored assuming that experts' backgrounds could lead to a narrow understanding of the issue compared to the multidisciplinary nature of the eight domains investigated.

During the team research workshop, comments were divided into three categories:

- Comments in disagreement with the metric that proposed additional contents underestimated in the framework;

- Comments in disagreement with the metric and in clear contrast with the literature review;

- Comments in agreement with the metric.

Results are summarized in Table 3. 
Table 3. Results of the questionnaires administrated among the experts and qualitative analysis of the related comments.

\begin{tabular}{|c|c|c|c|c|}
\hline Metric & Mean Score & Type of Comments & Main Contents of Comments & Implications \\
\hline 1.1. & 2.67 & In disagreement & $\begin{array}{l}\text { Experts agreed on considering the threshold of } 30 \% \text { of the monthly income to } \\
\text { address the housing costs as an unsustainable expenditure for older people. } \\
\text { Even if they acknowledge that this value is commonly regarded as the } \\
\text { adequate percentage, they pointed out the need to have more affordable } \\
\text { housing options for older people. }\end{array}$ & Included in the metric \\
\hline 2.1. & 4 & $\begin{array}{l}\text { In agreement. } \\
\text { No more contents proposed }\end{array}$ & $\begin{array}{l}\text { Experts agreed on the importance of private outdoor spaces to stimulate } \\
\text { socialization with the neighbors. }\end{array}$ & Metric unchanged \\
\hline 2.2. & 4.33 & $\begin{array}{l}\text { In agreement.No more contents } \\
\text { proposed }\end{array}$ & $\begin{array}{l}\text { Experts agreed on the fact that overlooking communal spaces is important to } \\
\text { make older people involved in the community life. They also argued that } \\
\text { enjoying a pleasant view from home impacts on their wellbeing. }\end{array}$ & Metric unchanged \\
\hline 2.3 . & 4.67 & $\begin{array}{l}\text { In agreement. } \\
\text { No more contents proposed }\end{array}$ & $\begin{array}{l}\text { Experts recognized the fundamental role played by sharing spaces in order to } \\
\text { encourage socialization and contrast loneliness. }\end{array}$ & Metric unchanged \\
\hline 3.1. & 4.33 & $\begin{array}{l}\text { In agreement. } \\
\text { No more contents proposed }\end{array}$ & $\begin{array}{l}\text { Experts shared the idea arising from literature of the positive impact that } \\
\text { living in a well-served area has on the wellbeing of older people. }\end{array}$ & Metric unchanged \\
\hline 4.1. & 4 & Partially in slight disagreement & $\begin{array}{l}\text { One of the experts disagreed with the metric. However, the concerns } \\
\text { connected to the falling risk are well documented in literature and the opinion } \\
\text { of the other experts is completely aligned with the proposed contents. }\end{array}$ & $\begin{array}{l}\text { Disagreement ignored } \\
\text { Metric unchanged }\end{array}$ \\
\hline 4.2 . & 3.33 & In slight disagreement & $\begin{array}{l}\text { Experts agreed with almost all contents of the metric. However, they } \\
\text { suggested to consider separately the effects that the crime rate of the area, the } \\
\text { presence of security services, and the sharing of the home environment with } \\
\text { others have on the sense of security. }\end{array}$ & Included in the metric \\
\hline 5.1. & 4.33 & Partially in slight disagreement. & $\begin{array}{l}\text { One of the experts did not think that an independent heating system is the best } \\
\text { requirement due to high costs involved. However, findings show that } \\
\text { calibrating internal temperature on the individual needs is important as older } \\
\text { people are more vulnerable to environmental conditions. Furthermore, the } \\
\text { metric refers to the energy-saving systems as the best standard to achieve in } \\
\text { compliance with the reduction in heating costs. }\end{array}$ & $\begin{array}{l}\text { Disagreement ignored } \\
\text { Metric unchanged }\end{array}$ \\
\hline 5.2 . & 4 & Partially in slight disagreement & As in the previous metric. & $\begin{array}{l}\text { Disagreement ignored } \\
\text { Metric unchanged }\end{array}$ \\
\hline 5.3 . & 3.33 & In slight disagreement & $\begin{array}{l}\text { Experts agreed with the contents of the metric but suggested to more properly } \\
\text { define uniform lighting. }\end{array}$ & Included in the metric \\
\hline
\end{tabular}


Table 3. Cont

\begin{tabular}{|c|c|c|c|c|}
\hline Metric & Mean Score & Type of Comments & Main Contents of Comments & Implications \\
\hline 5.4. & 3.67 & In slight disagreement & $\begin{array}{l}\text { Experts were aligned with literature review and considered technology as a } \\
\text { mean to support ageing in place. However, they argued that a cause of } \\
\text { concern is the high costs required by these systems. One of the experts also } \\
\text { stated that a different score should be assigned in relation to the priority of the } \\
\text { domotic system. } \\
\text { The research team did not change the metric because the housing systems costs } \\
\text { are already considered in the first domain. Furthermore, no research was } \\
\text { found to rate the domotic systems. }\end{array}$ & $\begin{array}{l}\text { Disagreement ignored. } \\
\text { Metric unchanged }\end{array}$ \\
\hline 6.1. & 4 & $\begin{array}{l}\text { In agreement. } \\
\text { No more contents proposed }\end{array}$ & $\begin{array}{l}\text { Experts agreed on the metric even if it is acknowledged that housing size } \\
\text { should be tailored on the personal capacities of older people. Furthermore, the } \\
\text { notion of overcrowding adopted is not considered relevant for the Italian } \\
\text { living conditions. }\end{array}$ & Included in the metric \\
\hline 6.2 . & 3.33 & In slight disagreement & $\begin{array}{l}\text { One of the experts suggested attributing a minor score to the outdoor private } \\
\text { spaces as this is a common feature of Italian houses. }\end{array}$ & Included in the metric \\
\hline 6.3 . & 3.67 & In slight disagreement & $\begin{array}{l}\text { One expert suggested evaluating the layout of houses in relation to the number } \\
\text { of inhabitants and the number of rooms. However, in the papers reviewed } \\
\text { there is a common understanding about the advantages for an older adult to } \\
\text { live in a house with a semi-open plan layout independently from other } \\
\text { conditions. }\end{array}$ & Metric unchanged \\
\hline 6.4 . & 5 & $\begin{array}{l}\text { In agreement. } \\
\text { No more contents proposed }\end{array}$ & All the experts strongly agree with the metric. & Metric unchanged \\
\hline 7.1. & 3.67 & In slight disagreement & $\begin{array}{l}\text { One of the experts suggested modifying the notion of accessibility for the } \\
\text { multi-storey houses including the possibility to have a room on the ground } \\
\text { floor to use as bedroom. }\end{array}$ & Included in the metric \\
\hline $\begin{array}{l}8.1 . \\
8.2 . \\
8.3 . \\
8.4 . \\
8.5 .\end{array}$ & 4.33 & $\begin{array}{l}\text { In agreement. } \\
\text { No more contents proposed }\end{array}$ & $\begin{array}{l}\text { All the experts acknowledged the importance of conducting predictive } \\
\text { maintenance to make houses more age-friendly. }\end{array}$ & Metric unchanged \\
\hline
\end{tabular}




\section{Discussion}

Home is an important determinant of wellbeing for older people. It can enable them to age in place improving their life and delaying institutionalization. To achieve this, the home environment must meet a number of requirements. A wide understanding of the topic has been provided by researchers who have investigated the relationship between housing features and health outcomes for older people. Furthermore, numerous criteria have been listed into guidelines and worksheets by national and international organizations to guide the design of age-friendly housing. The guidance provided by WHO [3] gives a comprehensive overview of the topic and has been used as the main reference for the present work. According to the domains identified in the guide, a qualitative systematic literature review has been conducted. Relevant papers that dealt with affordability, community connection, access to services, safety and security, essential services, design, modification, and maintenance were analyzed. During this process it emerged that some of the themes encountered in the WHO study were not recurrent topics in the literature review: Absence of essential services (electricity, gas, or water supply), lack of construction materials, and safety from natural disaster, for example, are seldom mentioned by authors. This can be due to the extensiveness of contexts addressed by the WHO guide, including developing countries.

In reviewing the literature, recurring subjects and results reported for each of the eight domains were recorded. Through qualitative analysis of the findings, the metrics of the framework were outlined. They summarized the evidence arising from the research related to the housing requirements that have been proved to affect the wellbeing of older people. The metrics were then converted in a score system ranging from 1 to 5 . The score system assigns the lowest score if the requirement is absent or if the performance is not consistent with the findings, and the highest score if all the requirements and performances mentioned by authors were fulfilled. The contents included in the metrics and in the rating system were then validated by a panel of experts. When experts proposed new contents underestimated in the framework or expressed a motivated disagreement with the metrics and the related score system, the metrics were changed. This process has led to a framework well supported by research evidence and experts' opinion.

Affordability of housing is commonly considered a concern for older people [3,37,38]. The threshold above which housing costs are regarded as affordable varies according to housing tenure type and the financial resources of older people [38]; even so, the value of $30 \%$ of disposable household income is commonly accepted $[7,38,39]$ as affordable. The experts suggested reducing this value: Two of them referred to the data of the Italian Social Insurance Institution (INPS) [123] according to which 70\% of private sector pensions amount to less than $€ 1000$ per month. For this reason, experts considered the threshold of $30 \%$ as an excessive burden on older people's economy that could be the cause of late payments, particularly if older people live in rented accommodation. Conversely, the experts reported that in Italy more than $70 \%$ of older people own their home, as confirmed by Falasca [20]. In this case, they considered the percentage of $30 \%$ of the disposable income too high to bear the costs of utilities, repair, and maintenance. The upper limit of $20 \%$ of monthly income for affordable housing costs has been therefore considered, coming closer to the value proposed by AARP [24].

Community connection can be supported by the home environment in different ways. The presence of outdoor private spaces is recognized as a means to be in contact with the neighborhood and to socialize [3,26,40-44]. Overlooking communal facilities from the home [3,44,48,49] and sharing spaces with neighbors $[46,48,49,51]$ are also mentioned when describing the housing features that improve community connection. Metrics have been specified in relation to the extent to which a dwelling promotes socialization. Experts agreed with the findings and the metrics proposed.

Access to services, which is described as the proximity of home to the main services like healthcare facilities, public transportation, and parks, enables independence of older people $[3,46,54,55]$ and stimulates their physical activity with positive implications on wellbeing [50,54,57,59,61]. Metrics have been defined assigning a score to the distance from home to services and to the quality of pathways. Experts were aligned with the literature review and did not provide any additional suggestions. 
Safety and Security refer to the risks to which older people are exposed in their home. Given that most findings reported falling as the main hazard for the safety of older people [65-67], the metric rates the housing features that reduce the risk of falling. This concept is strictly related to measures to undertake in the house to make it safer, such as the installation of a grab-bar or a shower seat in the toilet $[52,59,65,67,77]$. Experts agreed with the metric. Security in the home environment has been related to security from intruders. In this case, the context plays an important role: High crime rate and poor neighborhood conditions are the most common predictors of perceived insecurity among older people [79-82]. For this reason, physical security features which can detect the degree of security from burglars $[3,53,81]$ have been introduced in the metric. Sharing a home environment is mentioned when describing the conditions that improve security of older people [3] and this has been considered in the framework. Experts suggested assessing security from intruders and sharing of the home environment separately, as this last aspect is related to a more general perception of the security of an older adult.

Essential services have been included in the framework. The domain has been restricted to the features and performances of systems that can be adjusted to enhance the indoor comfort of older people (heating system, air-conditioning system, lighting system, and domotics) assuming that basic services like water supply and electricity are provided in all dwellings in western European countries. As a main feature of heating and cooling systems, the possibility to adapt indoor temperature to individual preference is mentioned $[47,79,83]$. Furthermore, the use of energy saving solutions is reported as an age-friendly feature due to the saving in heating or cooling costs $[48,83,84,87]$; the cost of energy was cited by experts in the validation process as a cause of concern. Lighting systems include a number of features that affect the comfort of older people. The most cited were the uniformity of light in all the rooms and task areas and the location and type of switches [76,90]. These parameters have been included in the metric conforming also to the opinion of experts. The domain of essential services also contains domotics. Its metric refers to the ease of use for older people as, according to the findings, this is the main barrier to the further uptake of smart home technologies [47,76,85,91-93]. Experts raised doubts regarding the costs involved in installing domotics and cited cost as limiting large-scale uptake of these technologies.

Design impacts several features of the wellbeing of older people. According to the findings, four main categories can be identified when considering the age-friendliness of a home: Housing size, room type, layout, and accessibility. No evidence was found in the literature on the minimum or maximum space that is adequate for an older adult and experts' opinion did not offer any further clarity, so the metric was defined in a qualitative way as suggested by the literature $[46,59]$. The notion of overcrowding of houses was removed from the metric as, according to the experts' opinion, this is not an issue for Italian older people. Furthermore, the ratio proposed by Eurostat [98] was not considered consistent with the common size of housing in which Italian older people live. With regard to room type, the presence of more than one bathroom [79], a caregiver's room [46,85], and outdoor spaces $[26,41,48,85,99]$ are cited as age-friendly features and were then included in the metric. Regarding the layout of the dwellings, authors reported the positive effects of having semi-open plan [48] and of reducing the number of doors, hallways, and rooms [69], above all for people living with dementia $[85,94]$. According to these findings, three schemes of the most common distribution of rooms have been included in the metric. They represent different configurations with an increasing amount of space for circulation increasing the ease of use of the home, especially for those with reduced mobility. The experts did not offer any further comment and one of them declared not to have an opinion, so the metric remained unchanged. Another key point of design is accessibility of the home environment [69]. The metric was aligned to the Italian regulation on accessibility [105] as the framework is tested in Italy. When creating the metric, information contained in the Italian documents have been improved with the contents provided in two other guidelines: The Lifetime Homes Criteria [27] and the Housing Enabler Instrument [106,107]. The experts completely agreed with this metric. 
Modification concerns the interventions to make the house more suitable for older people $[3,38,55,57,108]$. Interventions have been summarized in the metric as those that lead to increased accessibility. They were rated according to the technical difficulty of making such adaptations. This has been done to consider the two major concerns that older people face when deciding to modify their home: The costs involved and the difficulty in engaging tradespeople $[3,67,69,73,108,113]$. If adaptations are easy to make and do not require any spatial alteration, it is more likely that the costs involved are affordable and the involvement of tradespeople less challenging [108]. One of the experts suggested that the requirement of accessibility in multi-storey housing must take into account the possibility of allocating a bedroom on the ground floor and not just a bed-space. This suggestion has been included in the metric as it raises the quality standard of housing.

Maintenance is considered an important task to ensure a safe and a healthy home environment in which to age [55,115-118]. Predictable maintenance is undermined by the costs involved in maintaining and making repairs $[3,117,119,120]$ and by the difficulty in relying on someone to undertake the maintenance $[3,119]$. The provision of associations, persons of trust, or family that help older people in maintaining their homes is then considered an age-friendly feature $[119,121]$. For these reasons the metric considers two main factors in rating maintenance tasks: First of all, predictive maintenance has been assumed as the best strategy to adopt and a risk assessment of maintenance has been derived from the literature [115,122]; furthermore, the presence of a trusted person who can make the interventions is rated high in the metric. Experts agree with the findings and with the metric, although they were slightly concerned about the effective feasibility of predictable maintenance.

The final elaboration of the framework, coming from the literature review and the experts' opinion, is reported in the Table 4. 
Table 4. Metrics of the framework.

\begin{tabular}{|c|c|c|c|c|}
\hline ID & Domain & Assessment Area & Measurement Scale & Score \\
\hline \multicolumn{5}{|c|}{ 1. Affordability } \\
\hline 1.1. & Affordability & $\begin{array}{l}\text { Housing costs including: } \\
\text { - } \quad \text { Renting cost or mortgage payment; } \\
\text { - } \quad \text { Utilities; } \\
\text { - } \quad \text { Repair and maintenance costs }\end{array}$ & $\begin{array}{l}1 \text { - Housing costs are way above the affordability threshold (greater } \\
\text { than } 30 \% \text { ) } \\
2 \text { - Housing costs are above the affordability threshold (between } 20 \% \\
\text { and } 30 \% \text { ) } \\
3 \text { - Housing costs are about } 20 \% \text { of the monthly income } \\
4 \text { - Housing costs are under the affordability threshold (between } 20 \% \\
\text { and } 10 \% \text { ) } \\
5 \text { - Housing costs are way under the affordability threshold (less than } \\
10 \% \text { ) }\end{array}$ & $\begin{array}{l}1 \\
2 \\
3 \\
4 \\
5\end{array}$ \\
\hline \multicolumn{5}{|c|}{ 2. Community Connection } \\
\hline 2.1. & $\begin{array}{l}\text { Community } \\
\text { Connection }\end{array}$ & $\begin{array}{l}\text { Presence of outdoor private spaces (balconies, } \\
\text { terraces, patios, porches, gardens) }\end{array}$ & $\begin{array}{l}1 \text { - There are not outdoor spaces } \\
2 \text { - There are outdoor spaces but they are not accessible for people } \\
\text { with reduced mobility } \\
3 \text { - There are outdoor spaces accessible for people with reduced } \\
\text { mobility } \\
4 \text { - Outdoor spaces are accessible for people with reduced mobility } \\
\text { and provide adequate size for arranging tables, chairs, etc. } \\
5 \text { - Outdoor spaces are accessible for people with reduced mobility } \\
\text { and provide shelter from weather conditions and they also guarantee } \\
\text { privacy }\end{array}$ & $\begin{array}{l}1 \\
2 \\
3 \\
4 \\
5\end{array}$ \\
\hline 2.2. & $\begin{array}{l}\text { Community } \\
\text { Connection }\end{array}$ & Overlooking communal facilities and green areas & $\begin{array}{l}1 \text { - House overlooks facilities that are sources of disturbance } \\
\text { (noise/visual/odor pollution) } \\
2 \text { - House overlooks a communal facility } \\
3 \text { - House overlooks a green area } \\
4 \text { - The older adult can enjoy the view without impact on his privacy } \\
\text { (e.g., screened glass in the lower part of window) } \\
5 \text { - The older adult can enjoy the view even while sitting }\end{array}$ & $\begin{array}{l}1 \\
2 \\
3 \\
4 \\
5\end{array}$ \\
\hline
\end{tabular}


Table 4. Cont.

\begin{tabular}{|c|c|c|c|c|}
\hline ID & Domain & Assessment Area & Measurement Scale & Score \\
\hline 2.3 & $\begin{array}{l}\text { Community } \\
\text { Connection }\end{array}$ & Sharing spaces & $\begin{array}{l}1 \text { - There are not shared spaces } \\
2 \text { - Shared spaces are not accessible for people with reduced mobility } \\
3 \text { - There are shared spaces fully accessible for people with reduced } \\
\text { mobility } \\
4 \text { - There are shared spaces fully accessible for people with reduced } \\
\text { mobility. Within them activities take place, but only rarely } \\
5 \text { - There are shared spaces fully accessible for people with reduced } \\
\text { mobility. Within them activities take place habitually }\end{array}$ & $\begin{array}{l}1 \\
2 \\
3 \\
4 \\
5\end{array}$ \\
\hline \multicolumn{5}{|c|}{ 3. Access to Services } \\
\hline $\begin{array}{l}3.1 . \\
3.2 . \\
3.3 . \\
3.4 . \\
3.5 . \\
3.6 . \\
3.7 .\end{array}$ & Access to services & 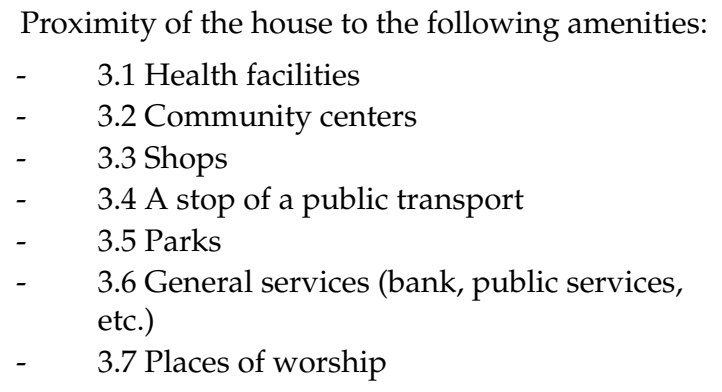 & $\begin{array}{l}1 \text { - Reaching the service needs more than } 20^{\prime} \text { walk } \\
2 \text { - Reaching the service needs between } 10^{\prime} \text { and } 20^{\prime} \text { walk along an } \\
\text { inaccessible and unsafe road } \\
3 \text { - Reaching the service needs less than } 10^{\prime} \text { walk along an inaccessible } \\
\text { and unsafe road } \\
4 \text { - Reaching the service needs between } 10^{\prime} \text { and } 20^{\prime} \text { walk along an } \\
\text { accessible and a safe road } \\
5 \text { - Reaching the service needs less than } 10^{\prime} \text { walk along an accessible } \\
\text { and a safe road }\end{array}$ & $\begin{array}{l}1 \\
2 \\
3 \\
4 \\
5\end{array}$ \\
\hline \multicolumn{5}{|c|}{ 4. Safety and Security } \\
\hline 4.1. & Safety and Security & $\begin{array}{l}\text { Safety measures refer to: } \\
-\quad \text { Adequate lighting; } \\
\text { - } \quad \text { Removal of obstacles along the pathways; } \\
\text { - } \quad \text { Removal or fixing rugs; } \\
\text { - } \quad \text { Grab bars and handrail; } \\
\text { - } \quad \text { Raised seats; } \\
\text { - } \quad \text { Non-slip surface }\end{array}$ & $\begin{array}{l}1 \text { - House does not prevent fall risk. No measure is undertaken to } \\
\text { guarantee the safety of the older adult } \\
2 \text { - House has a high fall risk. Less than two measures are undertaken } \\
\text { to guarantee the safety of older adult } \\
3 \text { - House has a medium fall risk. More than two measures are } \\
\text { undertaken to guarantee the safety of the older adult } \\
4 \text { - House has a low fall risk. All the measures are undertaken to } \\
\text { guarantee the safety of the older adult } \\
5 \text { - House has a low fall risk. All the measures are undertaken to } \\
\text { guarantee the safety of the older adult and a fall-detection system is } \\
\text { provided if fall occurs }\end{array}$ & $\begin{array}{l}1 \\
2 \\
3 \\
4 \\
5\end{array}$ \\
\hline
\end{tabular}


Table 4. Cont.

\begin{tabular}{|c|c|c|c|c|}
\hline ID & Domain & Assessment Area & Measurement Scale & Score \\
\hline 4.2.1. & Safety and Security & Security from entry by intruders & $\begin{array}{l}1 \text { - The older adult lives in context perceived as unsecure (high crime } \\
\text { rate, poor lighting around dwelling area, lack of surveillance) } \\
3 \text { - The older adult lives in a context perceived as secure (low crime } \\
\text { rate, good lighting around dwelling area, presence of surveillance) } \\
5 \text { - The older adult lives in a house located into a secure context (low } \\
\text { crime rate, good lighting around dwelling area, presence of } \\
\text { surveillance) and equipped with at least one security system }\end{array}$ & $\begin{array}{l}1 \\
3 \\
5\end{array}$ \\
\hline 4.2.2. & Safety and Security & Sharing of home environment & $\begin{array}{l}1 \text { - The older adult lives alone } \\
2 \text { - The older adult lives with another person that has a low level of } \\
\text { independence } \\
3 \text { - The older adult lives with a caregiver } \\
4 \text { - The older adult lives with another person that has a high level of } \\
\text { independence } \\
5 \text { - The older adult lives with more than one person and at least one } \\
\text { of them has a high level of independence }\end{array}$ & $\begin{array}{l}1 \\
2 \\
3 \\
4 \\
5\end{array}$ \\
\hline \multicolumn{5}{|c|}{ 5. Essential Services } \\
\hline 5.1. & Essential Services & Heating system & $\begin{array}{l}1 \text { - House has no heating system } \\
2 \text { - House is heated by individual devices (heater, fireplace, etc.) } \\
3 \text { - House has a centralised heating system } \\
4 \text { - House has an independent heating system } \\
5 \text { - House has an independent heating system and energy-saving } \\
\text { solutions are adopted }\end{array}$ & $\begin{array}{l}1 \\
2 \\
3 \\
4 \\
5\end{array}$ \\
\hline 5.2. & Essential Services & Air conditioning/air cooling system & $\begin{array}{l}1 \text { - House has no air-cooling system or air conditioning } \\
2 \text { - House is cooled by individual devices (fans, etc.) just in one part } \\
\text { of the house (living room or bedroom) } \\
3 \text { - House is cooled by individual devices (fans, etc.) both in living } \\
\text { room and bedroom } \\
4 \text { - House is cooled thanks to passive solar design solutions that } \\
\text { cooperate with individual devices (fans, etc.) } \\
5 \text { - House is cooled by individual devices (fans, etc.) and } \\
\text { energy-saving systems are provided }\end{array}$ & $\begin{array}{l}1 \\
2 \\
3 \\
4 \\
5\end{array}$ \\
\hline
\end{tabular}


Table 4. Cont.

\begin{tabular}{|c|c|c|c|c|}
\hline ID & Domain & Assessment Area & Measurement Scale & Score \\
\hline 5.3. & Essential Services & Lighting system & $\begin{array}{l}1 \text { - Lighting is inadequate. There are areas of glare and shadow } \\
2 \text { - Lighting is uniform throughout the house: All the rooms are well } \\
\text { illuminated and there are not areas of glare and shadow } \\
3 \text { - Lighting is uniform throughout the house and switches are well } \\
\text { located (near the bed, at both the beginning and the end of the stairs, } \\
\text { at the entrance of each room) } \\
4 \text { - Lighting is uniform throughout the house and task areas are also } \\
\text { well illuminated } \\
5 \text { - Lighting is uniform throughout the house and dimmers are } \\
\text { provided to adjust the light intensity according to the user's needs }\end{array}$ & $\begin{array}{l}1 \\
2 \\
3 \\
4 \\
5\end{array}$ \\
\hline $\begin{array}{l}\text { 5.4.1. } \\
\text { 5.4.2. } \\
5.4 .3 . \\
\text { 5.4.4. } \\
\text { 5.4.5. } \\
\text { 5.4.6. }\end{array}$ & Essential Services & $\begin{array}{l}\text { Domotics categories refer to: } \\
\text { 5.4.1. Lighting system } \\
\text { 5.4.2. Doors and windows opening and closing } \\
\text { system } \\
\text { 5.4.3. Heating and air conditioning systems } \\
\text { 5.4.4. Water system } \\
\text { 5.4.5. Alarms systems } \\
\text { 5.4.6. Smart meters }\end{array}$ & $\begin{array}{l}1 \text { - There is no domotics } \\
3 \text { - There is domotics, but the older person is not able to manage it } \\
\text { (this also includes systems with an unfamiliar interface) } \\
5 \text { - There is domotics and the older person is able to manage it (this } \\
\text { also includes systems with a familiar interface) }\end{array}$ & $\begin{array}{l}1 \\
3 \\
5\end{array}$ \\
\hline \multicolumn{5}{|l|}{ 6. Design } \\
\hline 6.1. & Design & Housing size & $\begin{array}{l}1 \text { - The house is too small: Spaces do not allow to safely perform } \\
\text { activities of daily living } \\
3 \text { - The house is too big: Space size is an obstacle preventing older } \\
\text { adult from moving or from adequately heating/cooling the rooms } \\
5 \text { - Housing size is adequate to the needs of older adult: Privacy is } \\
\text { guaranteed, spaces allow to safely perform activities and the physical } \\
\text { effort required to move inside the property is compatible with the } \\
\text { older adult's competence }\end{array}$ & $\begin{array}{l}1 \\
3 \\
5\end{array}$ \\
\hline
\end{tabular}


Table 4. Cont.

\begin{tabular}{|c|c|c|c|c|}
\hline ID & Domain & Assessment Area & Measurement Scale & Score \\
\hline 6.2. & Design & Rooms type & $\begin{array}{l}1 \text { - The house has not all the room required to perform activities of } \\
\text { daily living } \\
2 \text { - The house has all the room required to perform activities of daily } \\
\text { living } \\
3 \text { - The house has all the room required to perform activities of daily } \\
\text { living and has more than one bathroom } \\
4 \text { - The house has all the room required to perform activities of daily } \\
\text { living and has also a caregiver room } \\
5 \text { - The house has all the room required to perform activities of daily } \\
\text { living and has also outdoor private spaces apart from balcony (e.g., } \\
\text { terrace, garden, patio) }\end{array}$ & $\begin{array}{l}1 \\
2 \\
3 \\
4 \\
5\end{array}$ \\
\hline 6.3 & Design & Layout & $\begin{array}{l}1 \text { - The house has a corridor with rooms off } \\
3 \text { - The house has an entrance hall with rooms off } \\
5 \text { - The house has an open plan (that comprises kitchen, living room } \\
\text { and dining room) with separate bedroom and bathroom }\end{array}$ & $\begin{array}{l}1 \\
3 \\
5\end{array}$ \\
\hline $\begin{array}{l}6.4 .1 . \\
6.4 .2 . \\
6.4 .3 . \\
6.4 .4 . \\
6.4 .5 . \\
6.4 .6 . \\
6.4 .7 . \\
6.4 .8 . \\
6.4 .9 . \\
6.4 .10 . \\
6.4 .11 . \\
6.4 .12 . \\
6.4 .13 .\end{array}$ & Design & $\begin{array}{ll}\text { Accessibility categories refer to: } \\
-\quad & \text { 6.4.1 Pathway to approach house } \\
- & \text { 6.4.2 Entrance } \\
- & \text { 6.4.3 External stairs and lift } \\
- & \text { 6.4.4 Internal doors } \\
- & \text { 6.4.5 Hallways } \\
- & \text { 6.4.6 Windows } \\
- & \text { 6.4.7 Kitchen and living room } \\
- & \text { 6.4.8 Bathroom } \\
- & \text { 6.4.9 Bedroom } \\
- & \text { 6.4.10 Fixed furnishing } \\
- & \text { 6.4.11 Internal stairs } \\
- & \text { 6.4.12 Electrical outlets, counters, and } \\
\text { systems terminal in general } & \text { 6.4.13 Balconies and terraces }\end{array}$ & $\begin{array}{l}\text { Each category is: } \\
1 \text { - Inaccessible according to the requirements of DM 236/1989 } \\
3 \text { - Accessible according to the requirements of DM 236/1989 } \\
5 \text { - Best Practice. Accessible according to the requirements of DM } \\
236 / 1989 \text { with at least one higher performance. Higher performances } \\
\text { come from those listed in the Housing Enabler Instrument and/or in } \\
\text { the Lifetime Home Criteria }\end{array}$ & $\begin{array}{l}1 \\
3 \\
5\end{array}$ \\
\hline
\end{tabular}


Table 4. Cont.

\begin{tabular}{|c|c|c|c|c|}
\hline ID & Domain & Assessment Area & Measurement Scale & Score \\
\hline \multicolumn{5}{|c|}{ 7. Modification } \\
\hline $\begin{array}{l}7.1 .1 . \\
7.1 .2 . \\
7.1 .3 . \\
7.1 .4 . \\
7.1 .5 \\
7.1 .6 \\
7.1 .7 \\
7.1 .8 \\
7.1 .9 \\
7.1 .10 \\
7.1 .11 \\
7.1 .12 \\
7.1 .13\end{array}$ & Modification & $\begin{array}{l}\text { Interventions needed to make accessible: } \\
-\quad \text { 7.1 Pathway to approach house } \\
-\quad \text { 7.2 Entrance } \\
-\quad \text { 7.3 External stairs and lift } \\
-\quad \text { 7.4 Internal doors } \\
-\quad \text { 7.5 Hallways } \\
-\quad \text { 7.6 Windows } \\
-\quad \text { 7.7 Kitchen and living room } \\
-\quad \text { 7.8 Bathroom } \\
-\quad \text { 7.9 Bedroom } \\
-\quad \text { 7.10 Fixed furnishing } \\
-\quad \text { 7.11 Internal stairs } \\
-\quad \text { 7.12 Electrical outlets, counters, and systems } \\
\text { terminal in general } \\
\text { 7.13 Balconies and terraces }\end{array}$ & $\begin{array}{l}\text { To make it accessible: } \\
1 \text { - It is not possible to make it accessible (technically not possible) } \\
2 \text { - It is necessary to intervene on the frame or on the facilities } \\
3 \text { - It is necessary to intervene on masonry or bricked works } \\
4 \text { - It is necessary to intervene on flexible systems } \\
5 \text { - It is necessary to intervene with little interventions like moving } \\
\text { furniture, adding a grab bar, fixing anti-slip surfaces on stairs, etc. }\end{array}$ & $\begin{array}{l}1 \\
2 \\
3 \\
4 \\
5\end{array}$ \\
\hline 7.1.14. & & 7.14 Multi-level house & $\begin{array}{l}\text { To make it accessible: (in this case "accessible" means that at the } \\
\text { ground-floor the following accessible rooms are provided: A kitchen, } \\
\text { a living room, a bedroom, and a bathroom) } \\
1 \text { - It is not possible to make it accessible (technically not possible) } \\
2 \text { - It is necessary to intervene on the frame or on the facilities } \\
3 \text { - It is necessary to intervene on masonry or bricked works } \\
4 \text { - It is necessary to intervene on flexible systems } \\
5 \text { - It is necessary to intervene with little interventions like moving } \\
\text { furniture, adding a grab bar, fixing anti-slip surfaces on stairs, etc. }\end{array}$ & $\begin{array}{l}1 \\
2 \\
3 \\
4 \\
5\end{array}$ \\
\hline \multicolumn{5}{|c|}{ 8. Maintenance } \\
\hline 8.1.1. & Maintenance & $\begin{array}{l}\text { Cleaning and control interventions to undertake at } \\
\text { least one time over a seven-day period. } \\
\text { Category refers to: } \\
\quad \text { - 8.1.1 Cleaning of housing }\end{array}$ & $\begin{array}{l}1 \text { - Cleaning is made less than once a week } \\
3 \text { - Cleaning is made at least once a week } \\
5 \text { - Cleaning is made at least once a week. The older adult can rely on } \\
\text { himself or on a trusted person to make the interventions }\end{array}$ & $\begin{array}{l}1 \\
3 \\
5\end{array}$ \\
\hline
\end{tabular}


Table 4. Cont.

\begin{tabular}{|c|c|c|c|c|}
\hline ID & Domain & Assessment Area & Measurement Scale & Score \\
\hline $\begin{array}{l}\text { 8.2.1. } \\
8.2 .2 . \\
8.2 .3 . \\
8.2 .4 \\
8.2 .5 \\
8.2 .6\end{array}$ & Maintenance & $\begin{array}{l}\text { Cleaning and control interventions to undertake at } \\
\text { least one time over a 30-day period. } \\
\text { Categories refer to: } \\
\text { - } \quad \text { 8.2.1 Vertical interior finishes } \\
\text { - } \quad \text { 8.2.2 Internal doors and windows } \\
\text { - } \quad \text { 8.2.3 Disposal facility } \\
\text { - } \quad \text { 8.2.4 Heating and air-conditioning } \\
\text { systems devices } \\
\text { - } \\
\text { 8.2.5 Electric production systems } \\
\text { 8.2.6 Electrical outlets, counters, and systems } \\
\text { terminal in general }\end{array}$ & $\begin{array}{l}1 \text { - Cleaning and control are made less than once a month } \\
3 \text { - Cleaning and control are made at least once a month } \\
5 \text { - Cleaning and control are made at least once a month. The older } \\
\text { adult can rely on himself or on a trusted person to make the } \\
\text { interventions }\end{array}$ & $\begin{array}{l}1 \\
3 \\
5\end{array}$ \\
\hline $\begin{array}{l}8.3 .1 . \\
8.3 .2 . \\
8.3 .3 \\
8.3 .4\end{array}$ & Maintenance & $\begin{array}{l}\text { Inspections, checks, revisions, or replacements to } \\
\text { undertake at least every six months. } \\
\text { Categories refer to: } \\
\text { - } \quad \text { 8.3.1 External doors and windows } \\
\text { - } \quad \text { 8.3.2 Ceilings, flooring, and walls } \\
\text { - } \quad \text { 8.3.3 Stairs } \\
\text { - } \quad \text { 8.2.4 Heating and air-conditioning systems } \\
\text { (components and plumbing) }\end{array}$ & $\begin{array}{l}1 \text { - The activities have been undertaken more than six months ago } \\
3 \text { - The activities have been undertaken less than six months ago } \\
5 \text { - The activities have been undertaken less than six months ago. The } \\
\text { older adult can rely on a trusted person to make the interventions }\end{array}$ & $\begin{array}{l}1 \\
3 \\
5\end{array}$ \\
\hline $\begin{array}{l}8.4 .1 . \\
8.4 .2 . \\
8.4 .3 . \\
8.4 .4 \\
8.4 .5\end{array}$ & Maintenance & $\begin{array}{l}\text { Inspections, checks, revisions, or replacements to } \\
\text { undertake at least every year. } \\
\text { Categories refer to: } \\
\text { - } \quad \text { 8.4.1 Gas system (components and } \\
\text { system terminals) } \\
\text { - } \quad \text { 8.4.2 External coating } \\
\text { - } \quad \text { 8.4.3 Roof } \\
\text { - } \quad \text { 8.4.4 Sewage disposal system (components } \\
\text { and plumbing) } \\
\text { - 8.4.5 Water-sanitary systems (components) }\end{array}$ & $\begin{array}{l}1 \text { - The activities have been undertaken more than one year ago } \\
3 \text { - The activities have been undertaken less than one year ago } \\
5 \text { - The activities have been undertaken less than one year ago. The } \\
\text { older adult can rely on a trusted person to make the interventions, or } \\
\text { interventions involve other neighbors }\end{array}$ & $\begin{array}{l}1 \\
3 \\
5\end{array}$ \\
\hline
\end{tabular}


Table 4. Cont.

\begin{tabular}{|c|c|c|c|c|}
\hline ID & Domain & Assessment Area & Measurement Scale & Score \\
\hline 8.5.1. & \multirow{4}{*}{ Maintenance } & $\begin{array}{l}\text { Preventative maintenance or replacement of parts } \\
\text { at risk to undertake at least every five years. } \\
\text { Categories refer to: }\end{array}$ & \multirow{4}{*}{$\begin{array}{l}1 \text { - The activities have been undertaken more than five years ago } \\
3 \text { - The activities have been undertaken less than five years ago } \\
5 \text { - The activities have been undertaken less than five years ago. The } \\
\text { older adult can rely on a trusted person to make the interventions, or } \\
\text { interventions involve other neighbors }\end{array}$} & \multirow{4}{*}{$\begin{array}{l}1 \\
3 \\
5\end{array}$} \\
\hline 8.5.2. & & - $\quad$ 8.5.1 Electrical system (distribution cables) & & \\
\hline 8.5.3. & & 8.5.2 Gas system (plumbing) & & \\
\hline & & 8.5.3 Water-sanitary systems (plumbing) & & \\
\hline
\end{tabular}




\section{Conclusions and Future Research Implications}

The systematic qualitative review included in this research identifies the features of housing that enable older people to age in place. The results of this review were synthesized in a framework for the assessment of the age-friendliness of housing, founded and built on the guide proposed by WHO [3]. The framework firstly updates, contextualizes, and operationalizes the theoretical framework proposed by $\mathrm{WHO}[3]$ and secondly provides a comprehensive and forward-looking tool supported by a number of current international studies and guidelines. The metrics of the framework, that summarize the main results of the research, assign a score to the quality of home environments. This is a valuable contribution to address the need of age-friendly housing as metrics are an essential reference when designing interventions on existing or new houses.

The Italian experts involved in the study expressed a general agreement towards the metrics, further validating the framework. However, the importance that the context (intended as the cultural, social, and environmental context) has on the living environment and on the perception of its quality has emerged. According to the experts' opinion, some metrics have been modified to better assess the Italian living experience and conditions. This may limit the validity of the metrics in other countries. However, due to the international references used to build the framework, other countries can adopt it for the assessment of the age-friendliness of housing by adapting the metrics to the local context (e.g., to the local standards on accessibility) by recurring to a panel of local experts.

The present research is part of a larger study aimed at creating a composite indicator that assesses the age-friendliness of housing. To achieve this goal, apart from the construction of the framework presented here, a national-scale survey has been conducted among older people in Italy. The information derived from the literature review and from the experts' opinion has been further tested, asking older people the importance that the features of houses included in the metrics have on their wellbeing. In this way, a weight has been allocated to each metric of the framework. The scope is to create a tool that gives a measure of the suitability of the home environment according to quality criteria, derived from research and experts' opinions and the expectations of the end user of the house, i.e., older people. The results of the survey will be presented in another contribution.

Author Contributions: Conceptualization, A.L.; methodology, A.L. and F.P. (Federica Pascale); supervision, F.P. (Federica Pascale), F.P. (Francesco Polverino) and A.P.; validation, A.L. and F.P. (Federica Pascale); writing-original draft, A.L.; writing-review and editing, A.L., F.P. (Federica Pascale) and A.P. All authors have read and agreed to the published version of the manuscript.

Funding: This research received no external funding.

Acknowledgments: The authors especially thank the experts who agreed to participate in this study.

Conflicts of Interest: The authors declare no conflict of interest.

\section{References}

1. Lesthaeghe, R.J. Second Demographic Transition. Blackwell Encycl. Sociol. 2015, 1-5. [CrossRef]

2. Miccoli, C.M. Invecchiamento e Seconda Transizione Demografica; Dipartimento di Sicenze Economiche e Statisctiche: Fisciano, SA, USA, 2006.

3. WHO. Global Age-Friendly Cities: A Guide; WHO: Geneva, Switzerland, 2007.

4. OECD. Preventing Ageing Unequally; OECD Publishing: Paris, France, 2017.

5. UN. World Population Ageing 2013; United Nations publication, Department of Economic and Social Affairs, Population Division: New York, NY, USA, 2013.

6. United Nations. 2018 Revision of World Urbanization Prospects; United Nations, Department of Economic and Social Affairs, Population Division: New York, NY, USA, 2019.

7. WHO. Measuring the Age-Friendliness of Cities. A Guide to Using Core Indicators; WHO: Kobe, Japan, 2015.

8. Maus, M.; Satariano, A. Aging, Health, and the Environment: An Ecological Model 2. 9781284069389_CH02_Pass03.indd. Available online: http://samples.jbpub.com/9781284069389/Chapter2.pdf (accessed on 25 February 2019). 
9. United Nation. Transforming Our World: The 2030 Agenda for Sustainable Development. Resolution Adopted by the General Assembly on 25 September 2015. Available online: https://www.un.org/ga/search/ view_doc.asp?symbol=A/RES/70/1\&Lang=E (accessed on 3 March 2019).

10. Lawton, M.P. An Ecological Theory of Aging Apllied to Elderly Housing. J. Archit. Educ. 1977, 8-10. [CrossRef]

11. Nahemov, L.; Lawton, M.P. Toward and Ecological Theory of Adaptation and Aging. Available online: https://www.semanticscholar.org/paper/Toward-an-Ecological-Theory-of-Adaptation-and-AgingNahemow-Lawton/3757e42710488825d298ca3ea55ab112e5103c2d (accessed on 4 October 2019).

12. Iwarsson, S. A Long-Term Perspective on Person-Environemnt Fit and ADL Dependence among Older Swedish Adults. Gerontologist 2005, 45, 327-336. [CrossRef] [PubMed]

13. Baltes, M.M.; Maas, I.; Wilms, H.-U.; Borchelt, M.; Little, T.D. Everyday Competence in Old and Very Old Age: Theoretical Considerations and Empirical Findings. In The Berlin Aging Study. Aging from 70 to 100; Cambridge University Press: Cambridge, UK, 1999; pp. 384-402.

14. Oswald, F.; Wahl, H.-W. Dimensions of the meaning of home in later life. In Home and Identity in Late Life: International Perspectives; Springer: New York, NY, USA, 2005; pp. 21-45.

15. Lofqvist, C.; Tomsone, S.; Iwarsson, S.; Horstmann, V.; Haak, M. Changes in Home and Health over Nine Years among very Old People in Latvia-Results from the ENABLE-AGE project. J. Cross-Cult. Gerontol. 2017, 32, 17-29. [CrossRef] [PubMed]

16. Sixsmith, J.; Sixsmith, A.; Fänge, A.M.; Naumann, D.; Kucsera, C.; Tomsone, S.; Haak, M.; Dahlin-Ivanoff, S.; Woolrychc, R. Healthy ageing and home: The perspectives of very old people in five European countries. Soc. Sci. Med. 2014, 106, 1-9. [CrossRef]

17. Oswald, F.; Wahl, H.; Schilling, O.; Nygren, C.; Fänge, A.; Sixsmith, A.; Sixsmith, J.; Széman, Z.; Tomsone, S.; Iwarsson, S. Relationships Between Housing and Healthy Aging in Very Old Age. Gerontologist 2007, 47, 96-107. [CrossRef]

18. Binette, J.; Vasold, K. 2018 Home and Community Preferences Survey: A National Survey of Adults Age 18-Plus; AARP Research: Washington, DC, USA, 2018.

19. Smith, S.K.; Rayer, S.; Smith, E.; Wang, Z.; Zeng, Y. Population Aging, Disability and Housing Accessibility: Implications for Sub-national Areas in the United States. Hous. Stud. 2012, 27, 252-266. [CrossRef]

20. Falasca, C. Problemi e prospettive della domiciliaritá. Il diritto di invecchiare a casa propria; Edizioni LiberEtá: Roma, Italy, 2018.

21. Centers for Disease Control and Prevention. Healthy Places Terminology, 2009. Centers for Disease Control and Prevention (CDC). Available online: https://www.cdc.gov/healthyplaces/terminology.htm (accessed on 9 July 2019).

22. Lux, M.; Sunega, P. The impact of housing tenure in supporting ageing in place: Exploring the links between housing systems and housing options for the elderly. Int. J. Hous. Policy 2014, 14, 30-55. [CrossRef]

23. WHO. Large Analysis and Review of European Housing and Health Status (LARES); WHO: Geneva, Switzerland, 2007.

24. AARP Public Policy Institute. AARP Livability Index-Great Neighborhoods for All Ages, 2019. Available online: https://livabilityindex.aarp.org/livability-defined (accessed on 23 July 2019).

25. AARP. The AARP HomeFit Guide; AARP Education \& Outreach/Livable Communities: Washington, DC, USA, 2015.

26. HAPPI. Housing our Ageing Population: Panel for Innovation; Report; Homes and Communities Agency: London, UK, 2009.

27. The Foundation for Lifetime Homes and Neighbourhoods. Lifetime Home (LTH) Revised Criteria; Habinteg: London, UK, 2010.

28. RVCOG; AARP Oregon. Lifelong Housing Program. Available online: http://rvcog.org/home/sds-2/lifelonghousing-program/ (accessed on 5 June 2019).

29. Bockstaller, C.; Girardin, P. How to validate environmental indicators. Agric. Syst. 2003, 76, 639-653. [CrossRef]

30. Girardin, P.; Bockstaller, C.; Van der Werf, H. Indicators: Tools to Evaluate the Environmental Impact of Farming Systems. J. Sustain. Agric. 1999, 13, 5-21. [CrossRef] 
31. Mitchell, P.L.; Sheehy, J.E. Comparison of predictions and observations to assess model performance: A method of empirical validation. In Second International Symposium on Systems Approaches for Agricultural Development; RRI: Los Baños, Philippines, 1997; pp. 437-451.

32. Inglis, A. Approaches to the validation of quality frameworks for e-learning. Qual. Assur. Educ. 2008, 16, 347-362. [CrossRef]

33. Shields, T.J. Methodological Problems Associated with the Use of the Delphi Technique. Fire Technol. 1987, 23, 175-185. [CrossRef]

34. Von der Gracht, H.A. Consensus measurement in Delphi studies. Review and implications for future quality assurance. Technol. Forecast. Soc. Chang. 2012, 79, 1525-1536. [CrossRef]

35. Pankratova, N.D.; Malafeeva, L.Y. Formalizing the consistency of experts' judgments in the Delphi method. Cybern. Syst. Anal. 2012, 48,711-721. [CrossRef]

36. Alshehri, S.A.; Rezgui, Y.; Li, H. Delphi-based consensus study into a framework of community resilience to disaster. Nat. Hazards 2015, 75, 2221-2245. [CrossRef]

37. Vega, W.A.; Wallace, P. Affordable Housing: A Key Lever to Community health for Older Americans. Am. J. Public Health 2016, 106, 635-636. [CrossRef]

38. AARP. Housing Policy Solutions to Support Aging with Options; AARP Public Policy Institute: Washington, DC, USA, 2017.

39. Joint Center for Housing Studies of Harvard University. Housing America's Older People 2018; President and Fellows of Harvard College: Cambridge, MA, USA, 2018.

40. Brown, S.C. The relationship of built environment to perceived social support and psychological distress in Hispanic elders: The role of "eyes on the street". J. Gerontology. Ser. B Psychol. Sci. Soc. Sci. 2009, 64, 234-246. [CrossRef]

41. Burton, E.; Mitchell, L.; Stride, C. Bed of roses? The role of garden space in older people's well-being. Urban Des. Plan. 2015, 168, 164-173. [CrossRef]

42. Morrison, A. Housing suitable for an ageing population. Work. Older People 2016, 20, 204-208. [CrossRef]

43. Levasseur, M. Importance of proximity to resources, social support, transportation and neighborhood security for mobility. BMC Public Health 2015, 15, 2-19. [CrossRef]

44. Sixsmith, J.; Sixsmith, A.; Dahlin-Ivanoff, S. Influence of occupation and home environment on the wellbeing of European elders. Int. J. Ther. Rehabil. 2005, 12, 505-509. [CrossRef]

45. Marshall, M. Designing balconies, toof terraces, and roof gardens for people with dementia. J. Care Serv. Manag. 2010, 5, 156-159. [CrossRef]

46. Ervet. Guidelines for the Planning of Houses for Senior Citizens, 2007. Available online: https://www.housinglin. org.uk/_assets/Resources/Housing/Support_materials/Other_reports_and_guidance/1-32_E.pdf (accessed on 11 June 2019).

47. Hadjri, K.; Morris, D.; Akintoye, A.; Buffin, J.; Gadakari, T.; Bola, M.; Wang, J. Age-friendly housing environments. In Optimising Care Delivery Models to Support Ageing-in-Place; Odessa Symposium Publication: Sheffield, UK, 2019; pp. 8-14.

48. Park, J.; Porteus, J. Age-Friendly Housing. Future Design for Older People; RIPA Publishing: London, UK, 2018.

49. Cocco, F.; Pibiri, R. Residenze sociali con servizi per anziani. Il modello della "vivienda dotacional" del Comune di Barcellona. In Proceedings of the Quarta conferenza annuale ESPAnet Italia 2011. Innovare il welfare. Percorsi di trasformazione in Italia e in Europa, Milano, Italy, 29 September-1 Octember 2011; pp. 1-22.

50. Annear, M.; Keeling, S.; Wilkinson, T.; Cushman, G.; Gidlow, B.; Hopkins, H. Environmental influences on healthy and active ageing: A systematic review. Ageing Soc. 2014, 34, 590-622. [CrossRef]

51. Radka, J. Social Connections in Extra Care Living: Bridging the Gap between Academic Research, Theory and Practice to Create Successful Extra Care Homes. Univeristy of Nottingham. Available online: https://www.housinglin.org.uk/_assets/Resources/Housing/OtherOrganisation/Social-connections-inextra-care-living-Bridging-the-gap-between-academic-research-theory-and-practice-to-create-successfulextra-care-homes.pdf (accessed on 11 July 2019).

52. Arup. Cities Alive. Designing for Ageing Communities; Arup: London, UK, 2019.

53. The National Affordable homes Agency. 721 Housing Quality Indicators (HQI) Form; Housing Corporation: London, UK, 2008. 
54. Canada Mortgage and Housing Corporation. Community Indicators for an Aging Population. Available online: https://www.cmhc-schl.gc.ca/odpub/pdf/66099.pdf (accessed on 16 May 2019).

55. Boldy, D.; Grenade, L.; Lewin, G. Older people's decisions regarding "ageing in place": A Western Australian case study. Australas. J. Ageing 2010, 30, 136-142. [CrossRef]

56. Morris, D.; Akintoye, A.; Buffin, J.; Gadakari, T.; Bola, M.; Wang, J. Healthy ageing-in-place: The role of social connection, networks and community belonging. In Optimising Care Delivery Models to Support Ageing-in-Place; Odessa Symposium Publication: Sheffield, UK, 2019; pp. 1-7.

57. Arup, Help Age International, Intel, Systematica. Shaping Ageing Cities: 10 European Case Studies; Arup, Help Age International, Intel, Systematica: London, UK, 2015.

58. Sun, Y.; Philips, D.R.; Wong, M. A study of housing typology on perceived age-friendliness in an established Hong Kong new town: A person-environment perspective. Geoforum 2018, 88, 17-27. [CrossRef]

59. Brookfield, K.; Fitzsimons, C.F.; Scott, I.; Mead, G.E.; Starr, J.; Thin, N.; Tinker, A.; Thompson, C.W. The home as enabler of more active lifestyles among older people. Build. Res. Inf. 2015, 43, 616-630. [CrossRef]

60. Li, F.; Fisher, K.J.; Brownson, R.C.; Bosworth, M. Multilevel modelling of built environment characteristics related to neighbourhood walking activity in older people. J. Epidemiol. Community Health 2005, 59, 558-564. [CrossRef]

61. Renalds, A.; Smith, T.H.; Hale, P.J. A Systematic review of Built Environment and Health. Fam. Community Health 2010, 33, 68-78. [CrossRef]

62. Loo, B.P.Y. How Is the Neighborhood Environment Related to the Health of Seniors Living in Hong Kong, Singapore, and Tokyo? Some Insights for Promoting Aging in Place. Ann. Am. Assoc. Geogr. 2017, 107, 812-828. [CrossRef]

63. Lehning, A.; Smith, R.J.; Dunkle, R.E. Age-Friendly Environments and Self-Rated Health: An Exploration of Detroit Elders. Res. Ageing 2012, 36, 72-94. [CrossRef]

64. Kamin, S.T.; Beyer, A.; Lang, F.R. Outdoor motivation moderates the effects of accessibility on mobility on old age. Zeitschrift für Gerontologie GeriatrieZeitschrift für Gerontologie Geriatrie 2016, 49, 372-378. [CrossRef]

65. PNLG, Programma Nazionale Linee Guida. Prevenzione delle cadute da incidente domestico negli anziani. Linea guida; Zadig: Milano, Italy, 2007.

66. Keskinoglu, P. Home Accidents in the Community-Dwelling Elderly in Izmir, Turkey. How Do Prevalence and Risk Factors Differ Between High and Low Socioeconomic Districts? J. Aging Health 2008, 20, 824-836. [CrossRef] [PubMed]

67. Meucci, M.M.; Gozalo, P.; Dosa, D.; Allen, S.M. Variation in the Presence of Simple Home Modifications of Older Americans: Findings from the National Health. J. Am. Geriatr. Soc. 2016, 64, 2081-2087. [CrossRef]

68. Carter, S.E.; Campbell, E.M. Accidents in older people living at home: A community-based study assessing prevalence, type, location and injuries. Aust. N. Z. J. Public Health 2000, 24, 633-636. [CrossRef] [PubMed]

69. Bamzar, R. Assessing the quality of the indoor environment of senior housing for a better mobility: A Swedish case study. J. Hous. Built Environ. 2019, 34, 23-60. [CrossRef]

70. Cesari, M.; Landi, F.; Torre, S.; Onder, G.; Lattanzio, F.; Bernabei, R. Prevalence and Risk Factors for Falls in an Older Community-Dwelling Population. J. Gerontol. Med Sci. 2002, 57, M722-M726. [CrossRef]

71. Istituto superiore di sanitá. Le cadute negli anziani. Available online: https://www.epicentro.iss.it/incidentidomestici/rischi-cadute-anziani\#cause (accessed on 12 April 2019).

72. Rosnah, M.Y.; Sharifah Norazizan, S.A.R.; Tengku Aizan, H.; Hussain, M.R. Home Living Environment Design and Perceptions of Safety of Older Malaysians. Gerontechnology 2008, 7, 201. [CrossRef]

73. Gitlin, L.N.; Mann, W.; Tomit, M.; Marcus, S.M. Factors associated with home environmental problems among community-living older people. Disabil. Rehabil. 2001, 23, 777-787. [CrossRef]

74. Lowery, K.; Buri, H.; Ballard, C. What is the prevalence of environmental hazards in the homes of dementia sufferers and are they associated with falls. Int. J. Geriatr. Psychiatry 2000, 15, 883-886. [CrossRef]

75. Feldman, F.; Chaudhury, H. Falls and physical environment: A review and a new multifactorial falls-risk conceptual framework. Revue Canadienne d'Ergothérapie 2008, 75, 82-95. [CrossRef]

76. Van Hoof, J.; Korta, H.S.M.; Duijnstee, M.S.H.; Rutten, P.G.S.; Hensen, J.L.M. The indoor environment and the integrated building design of homes for older people with dementia. Build. Environ. 2010, 45, 1244-1261. [CrossRef]

77. Lu, X.; Park, N.K.; Ahrentzen, S. Lighting Effects on Older people' Visual and Nonvisual Performance: A Systematic Review. J. Hous. Elder. 2019, 33, 298-324. [CrossRef] 
78. NICE. Falls in Older People: Assessing Risk and Prevention. Clinical Guideline; National Institute for Health and Care Excellence: London, UK, 2013.

79. Lawton, M.P. Housing the Elderly. Residential Quality and Residential Satisfaction. Res. Aging 1980, 2, 309-328. [CrossRef]

80. Van der Pas, S.; Ramklass, S.; O'Leary, B.; Anderson, S.; Keating, N.; Cassim, B. Features of home and neighbourhood and the liveability of older South Africans. Eur. J. Ageing 2015, 12, 215-227. [CrossRef] [PubMed]

81. Department for Communities and Local Government. Housing Health and Safety Rating System. Guidance for Landlords and Property Related Professionals; Department for Communities and Local Government: London, UK, 2006.

82. Kim, M.; Clarke, P. Urban Social and Built Environments and Trajectories of Decline in Social Engagement in Vulnerable Elders: Findings From Detroit's Medicaid Home and Community-Based Waiver Population. Res. Aging 2015, 37, 413-435. [CrossRef] [PubMed]

83. Van Hoof, J.; Schellen, L.; Soebarto, V.; Wong, J.K.W.; Kazak, J.K. Ten question concerning thermal comfort and ageing. Build. Environ. 2017, 120,123-133. [CrossRef]

84. Van Hoof, J.; Kort, H.S.M.; Hensen, J.; Duijnstee, M.S.H. Thermal comfort and the integrated design of homes for older people with dementia. Build. Environ. 2010, 45, 358-370. [CrossRef]

85. Van Hoof, J.; Kort, H.S.M. Supportive living environments: A first concept of a dwelling designed for older people with dementia. Dementia 2009, 8, 293-316. [CrossRef]

86. WHO. Housing and Healt Guidelines; WHO: Geneva, Switzerland, 2018.

87. Miller, W.; Vine, D.; Amin, Z. Energy efficiency of housing for older citizens: Does it matter? Energy Policy 2017, 101, 216-224. [CrossRef]

88. Barstow, B.A.; Bennett, D.K.; Vogtle, L.K. Perspectives on Home Safety: Do Home Safety Assessments Address the Concerns of Clients With Vision Loss? Am. J. Occup. Ther. 2011, 65, 635-642. [CrossRef]

89. Leung, M.; Yu, Y.; Chow, H. Impact of indoor facilities management on the quality of life of the elderly in public housing. Facilities 2016, 34, 564-579. [CrossRef]

90. Lighting Research Center. Lighting the Way: A Key to Independence; Rensselaer Polytechnic Institute: New York, NY, USA, 2001.

91. Kerbler, B. An innovative built environment form for dwellings for the elderly. METU J. Fac. Archit. 2014, 31, 119-137. [CrossRef]

92. Peruzzini, M.; Germani, M.; Papetti, A.; Iualè, M. Design of sustainable smart homes for elderly. Int. J. Des. Sci. Technol. 2015, 22, 7-30.

93. Wong, J.K.W.; Leung, J.; Skitmore, M.; Buys, L. Technical requirements of age-friendly smart home technologies in high-rise residential buildings: A system. Autom. Constr. 2017, 73, 12-19. [CrossRef]

94. Marquardt, G.; Johnston, D.; Black, B.S.; Morrison, A.; Rosenblatt, A.; Lyketsos, C.G.; Samus, Q.M. Association of the spatial layout of the home and ADL abilities among older people with dementia. Am. J. Alzheimer's Dis. Other Dement. 2011, 26, 51-57. [CrossRef] [PubMed]

95. Oswald, F.; Jopp, D.; Rott, C.; Wahl, H. Is aging in place a resource for or risk to life satisfaction? Gerontologist 2011, 51, 238-250. [CrossRef]

96. Cress, M.E.; Orini, S.; Kinsle, L. Living Environment and Mobility of Older people. Gerontology 2011, 57, 287-294. [CrossRef]

97. Ahrentzen, S.; Tural, E. The role of building design and interiors in ageing actively at home. Build. Res. Inf. 2015, 43, 582-601. [CrossRef]

98. Eurostat. Glossary: Overcrowding rate. Available online: https://ec.europa.eu/eurostat/statistics-explained/ index.php/Glossary:Overcrowding_rate (accessed on 24 March 2019).

99. Dongsook, K.; Kazuoki, O. A study on the role of gardening and planning of green environemnts for daily use by residents in Senior Housing. J. Asian Archit. Build. 2010, 9, 55-61. [CrossRef]

100. Granbom, M.; Slaug, B.; Löfqvist, C.; Oswald, F.; Iwarsson, S. Community Relocation in Very Old Age: Changes in Housing Accessibility. Am. J. Occup. Ther. 2016, 70, 01-09. [CrossRef]

101. Chan, S.; Ellen, I.G. Housing for an Aging Population. Hous. Policy Debate 2017, 27, 167-192. [CrossRef]

102. Eriksen, M.D.; Greenhalgh-Stanley, N.; Engelhardt, G.V. Home safety, accessibility, and elderly health: Evidence from falls. J. Urban Econ. 2015, 87, 14-24. [CrossRef] 
103. AARP. Increasing Home Access: Designing for Visitability; AARP Public Policy Institute: Washington, DC, USA, 2008.

104. Petersson, I.; Kottorp, A.; Bergström, J.; Lilja, M. Longitudinal changes in everyday life after home modifications for people aging with disabilities. Scand. J. Occup. Ther. 2009, 16, 78-87. [CrossRef] [PubMed]

105. Decreto del Ministro dei lavori pubblici, 14 giugno 1989, n. 236, "Prescrizioni tecniche necessarie a garantire l'accessibilità, l'adattabilità e la visitabilità degli edifici privati e di edilizia residenziale pubblica, ai fini del superamento e dell'eliminazione delle barriere architettoniche.". Available online: http://www.mit.gov.it/ mit/mop_all.php?p_id=12648 (accessed on 28 April 2019).

106. Iwarsson, S.; Slaug, B. The Housing Enabler Screening Tool. Environmental Assessment, 2018. Available online: http://www.enabler.nu/Environmental_barriers.pdf (accessed on 17 February 2019).

107. Iwarsson, S.; Slaugh, B.; Fange, A. The Housing Enabler Screening Tool Feasibility and Interrater Agreement in a Real Estate Company Practice. J. Appl. Gerontol. 2012, 31, 641-660. [CrossRef]

108. AARP. Home Modifications to Promote Independent Living, Fact Sheet 168; AARP Public Policy Institute: Washington, DC, USA, 2010.

109. Aliberti, M.J.R.; Covinsky, K.E. Home Modifications to Reduce Disability in Older people With Functional Disability. JAMA Intern. Med. 2019, 179, 211-212. [CrossRef] [PubMed]

110. Steinman, B.A.; Pynoos, J.; Nguyen, A.Q.D. Fall Risk in Older people. J. Aging Health 2009, 21, 655-676. [CrossRef]

111. Carnemolla, P.; Bridge, C. Housing Design and Community Care: How Home Modifications Reduce Care Needs of Older People and People with Disability. Int. J. Environ. Res. Public Health 2019, 16, 1951. [CrossRef]

112. Kim, H.; Ahn, Y.H.; Steinhoff, A.; Lee, K.H. Home modification by older people and their informal caregivers. Arch. Gerontol. Geriatr. 2014, 59, 648-656. [CrossRef]

113. Bayer, A.E.; Harper, L. Fixing to Stay. A National Survey on Housing and Home Modification Issues; AARP: Washington, DC, USA, 2000.

114. Demirkan, H. Housing for the aging population. Eur. Rev. Aging Phys. Act. 2007, 4, 33-38. [CrossRef]

115. AARP. Here to Stay: Home Upkeep for All; AARP Foundation: Washington, DC, USA, 2019.

116. Fausset, B.C.; Kelly, A.J.; Rogers, W.A.; Fisk, A.D. Challenges to Aging in Place: Understanding Home Maintenance Difficulties. J. Hous. Elder. 2011, 25, 125-141. [CrossRef]

117. Coleman, T.; Kearns, R.A.; Wiles, J. Older adults' experiences of home maintenance issues and opportunities to maintain ageing in place. Hous. Stud. 2016, 31, 964-983. [CrossRef]

118. Begley, J.; Lambie-Hanson, L. The Home Maintenance and Improvement Behaviors of Older people in Boston. Hous. Policy Debate 2015, 25, 754-781. [CrossRef]

119. James, B.; Saville-Smith, K.; Jacques, R. Tools for Good Homes for Ageing in Place. In Proceedings of the 6th Australiasian Housing Researchers' Conference, Adelaide, Australia, 8-10 February 2012; pp. 1-18.

120. Littlewood, A.; Munro, M. Explaining disrepair. Examining owner occupiers' repair and maintenance bahaviour. Hous. Stud. 1996, 11, 503-525. [CrossRef]

121. Boyle, F.; Thomson, C. Establishing an evidence base for adapting social housing for an ageing population. J. Financ. Manag. Prop. 2016, 21, 137-159. [CrossRef]

122. Molinari, C. Procedimenti e metodi della manutenzione edilizia; Sistemi Editoriali: Napoli, Italy, $2002 ;$ Volume 1.

123. INPS. Pensioni vigenti all'1.1.2019 e liquidate nel 2018 erogate dall'Inps. Available online: http://www. bollettinoadapt.it/osservatorio-pensioni-vigenti-all1-1-2019-e-liquidate-nel-2018-erogate-dallinps/ (accessed on 30 October 2019).

(C) 2020 by the authors. Licensee MDPI, Basel, Switzerland. This article is an open access article distributed under the terms and conditions of the Creative Commons Attribution (CC BY) license (http://creativecommons.org/licenses/by/4.0/). 